\title{
Brachiopods and crinoids from the Middle-Upper Devonian boundary beds in the Darende-Gürün and Van-Zincirkıran areas (Eastern Taurus, Turkey)
}

\author{
RÉMY GOURVENNEC \& IZZET HOŞGÖR
}

\begin{abstract}
Two new sections in the Eastern Taurides, Turkey, have yielded brachiopods and crinoids of Middle-Late Devonian age. Fifteen brachiopod species, among them two are new (Paillettia menae sp. nov. and Eodmitria sezgini sp. nov.) and three crinoid species have been identified. A late Givetian to early Frasnian age has been established for these sections based on the brachiopods, whereas crinoids rather indicate a late Givetian age. This fossil assemblage reflects strong affinities with Gondwanan and peri-Gondwanan domains. • Key words: brachiopods, crinoids, Devonian, Gümüșali Formation, Turkey, new species.
\end{abstract}

GOURVENNEC, R. \& HOȘGÖR, İ. 2015. Brachiopods and crinoids from the Middle-Upper Devonian boundary beds in the Darende-Gürün and Van-Zincirkıran areas (Eastern Taurus, Turkey). Bulletin of Geosciences 90(3), 577-600 (10 figures, 3 tables). Czech Geological Survey, Prague. ISSN 1214-1119. Manuscript received June 27, 2014; accepted in revised form May 22, 2015; published online June 18, 2015; issued September 30, 2015.

Rémy Gourvennec (corresponding author), CNRS UMR 6538 “Domaines Océaniques”, IUEM, Université de Bretagne Occidentale, Avenue Le Gorgeu, CS 93837, F-29238 Brest, France; remy.gourvennec@univ-brest.fr •İzzet Hoşgör, Çalık Enerji, Petrol ve Gaz Grubu, Ak Plaza, Yașam Caddesi No. 7 - Kat 9, Söğütözü -Ankara, Turkey; izzet.hosgor@calikenerji.com

Studies on Paleozoic brachiopods and crinoids in Turkey are few, especially in the region of Van. A lot of our current knowledge is based on old and unreliable determinations in the light of current methods. The latter are often complicated by poor preservation. That is why the key knowledge relies on micropaleontological data, less sensitive to bad conditions generated by tectonics. In the context of a petroleum exploration, one of us (İ.H.) was able to collect some samples of macrofauna. Despite its scarcity and unfavorable preservation, it seemed useful to unveil all of this material that shows an obvious diversity and represents a further step in understanding the complex stratigraphy of the Eastern Taurids. Two new species of spiriferides with very particular features making them easy to identify should be useful elements for future correlations between different regions of the Eastern Taurids and even beyond. Uncertainties inherent to the quality of material restrict to some extent the strength of paleogeographic conclusions. However we make an attempt to compare the present fauna with the same or age-equivalent faunas known from elsewhere in the world.

\section{Geological setting}

The Taurus Belt, as a part of the Alpine-Himalayan oroge- nic system, is located along the southern portion of Anatolia, covering an area of about $127,500 \mathrm{~km}^{2}$. Three major faults oriented from north to south divide the Taurus Belt into three geographic parts from the east to the west (Fig. 1): (1) The area of the eastern Taurus region bordered in the east by the East Anatolian Fault and in the west by the Ecemis Fault, (2) the central Taurus region located between the Ecemis Fault in the east and the Krrkkavak Fault in the west, and (3) the western Taurus region lies between the Kirkkavak Fault and the Aegean Sea (Fig. 1; Özgül 1976).

Devonian units of different litho-types and of different paleogeographic origin are parts of thick Paleozoic sedimentary successions of the Pontides, Taurides and Arabian Plate. In the Taurides of Southern Turkey, Özgül (1976) distinguished six different tectono-stratigraphic units: Geyikdağ Unit, Aladağ Unit, Bolkardağ Unit, Bozkır Unit, Alanya Unit and Antalya Unit. The present study is performed in the Geyikdağ Unit of the Eastern Taurides. The parautochthonous Geyikdağ Unit with its CambrianLower Carboniferous succession includes most of the Paleozoic units in this region. Devonian sequences of the Geyikdağ Unit in the Eastern Taurides are represented in terms of lithostratigraphic units by the Ayitepesi, Șafaktepe and Gümüșali formations (Fig. 1A, B). The general 


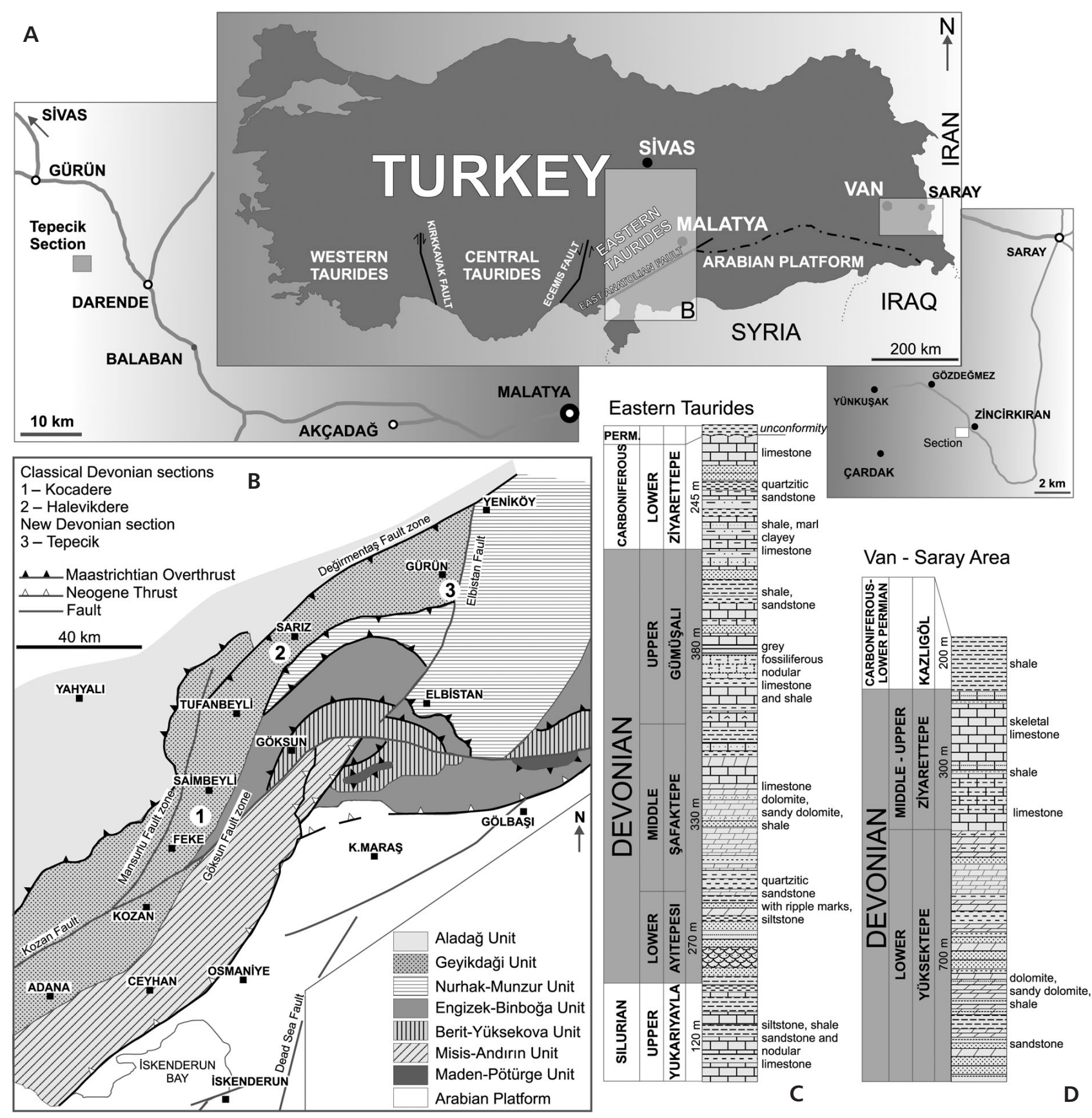

Figure 1. A - geographical subdivision of the Taurus Belt (after Özgül 1976) and location of the study area. • B - tectonic units of the Eastern Taurides (after Özgül 1976). • C - generalized stratigraphic section of Paleozoic units in the Eastern Taurides. Devonian successions are part of the para-autochthonous Geyikdağ Unit (modified from Yalçın \& Yılmaz 2010). D - generalized stratigraphic section of Paleozoic units in the Turkey-Iran boundary and location of the Zincirkıran section (after Șenel 1987).

characteristics of these units are summarized in the following based on Yalçın \& Yılmaz (2010) and Wehrmann et al. (2010). The principal classical outcrops of Devonian units in the Eastern Taurides cover a wide area striking SW-NE from Kozan to Sarız (Fig. 1B). Well measurable outcrops of these units in the Eastern Taurides are observed north of Adana near Sarı, Tufanbeyli, Saimbeyli, and Feke. The sections have an average thickness of 1000 to $1200 \mathrm{~m}$. A detailed description of Devonian successions in the Eastern Taurides is given with reference to the sections studied by Wehrmann et al. (2010).

A recent field work in the Paleozoic succession of Gürün allowed the sampling of fossils collected bed by bed in the Devonian strata (Figs 1B, 2A, B). The study area is 
located northeast to the "classical lithostratigraphic unit at outcrop in Saimbeyli-Adana, Kocadere Section and Sarı-Kayseri, Halevikdere Section" where the Ayıtepesi, Șafaktepe and Gümüșali formations are well exposed. Many recent studies have reported the rich fauna in the Taurides (Blumenthal 1944, Ünsalaner 1951, Demirtașlı 1967, Özgül et al. 1972, Tutkun 1984, Nalc1oğlu 2004, Gourvennec 2006, Webster et al. 2008, Sayar et al. 2009, Nazik et al. 2012).

The Devonian sequence overlies the Silurian in conformity and is conformably overlain by the Carboniferous (Fig. 1C). The Devonian includes three formations that approximately correspond to the series of this period. The Ayi Tepesi Formation (Fig. 1C), described for the first time by Özgül et al. (1973), represents the Lower Devonian and passes conformably into the Middle Devonian Safak Tepe Formation consisting of platform deposits (Demirtaşl 1967) to which succeeds, also in conformity, the Gümüșali Formation formed by a succession of limestones, shales and sandstones. The latter is rich in fossils (mainly brachiopods, corals, gastropods and bryozoans; Fig. 1C). Towards the top, the supply in detrital elements increases (Atabey 1996, Yalçın \& Yılmaz 2010). Göncüoğlu et al. (2004), considering the conodont fauna, suggested a Middle Givetian to Frasnian age for this formation while Çapkınoğlu \& Gedik (2000) suggested that the polygnathid-icriodid biofacies indicates a coastal environment.

\section{The Tepecik and Zincirkiran sections}

Little is known on the Paleozoic paleontology of the Devonian period in the Darende-Gürün area of the Eastern Taurides, although the oil industry has been working in the region for many years. Sections of the Devonian successions in the Gürün area were systematically sampled and worked in 2011-2012 for geological and stratigraphical investigations, by Petroleum geologist Dr Sezgin Aytuna and one of us (İ.H.).

The new records of brachiopods reported here come from the Gümüșali Formation, in the Tepecik section, located in the southeastern part of the Gürün area (Figs 2A, 3). The Tepecik section is located $10 \mathrm{~km}$ southeast of Gürün, at latitude $38^{\circ} 44^{\prime} 52.30^{\prime \prime} \mathrm{N}$ and longitude $37^{\circ} 28^{\prime} 35.50^{\prime \prime} \mathrm{E}$. No reliable estimates of the succession are available from the litterature. Patrut (1968a) in his regional map showed the position of the quarry in the outcrop belt of the Devonian sequences. This basic work, however, which was intended to accompany the geological map of the Darende-Gürün Basin, was never published, and original information about these units had to be adopted from a later work by Patrut (1968b). Only a few attempts have been made so far to sketch Devonian and Permian facies patterns in the SW Sivas area (Baykal 1945; Bulut 1964;
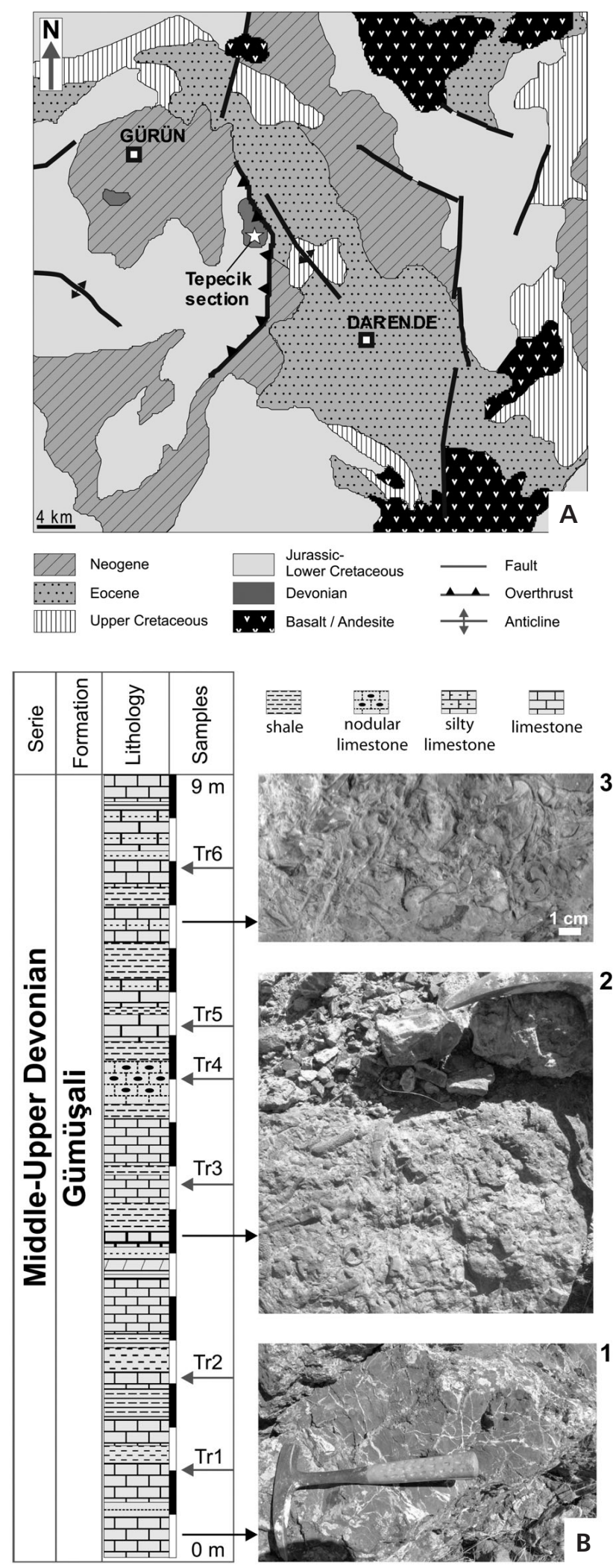

Figure 2. A - location of the Devonian brachiopod sites in the Gürün area. Simplified geological map after Kurtman \& Akkuș (1974). - B - measured stratigraphic section of the Gümüșali Formation and some typical facies of the Tepecik section. 


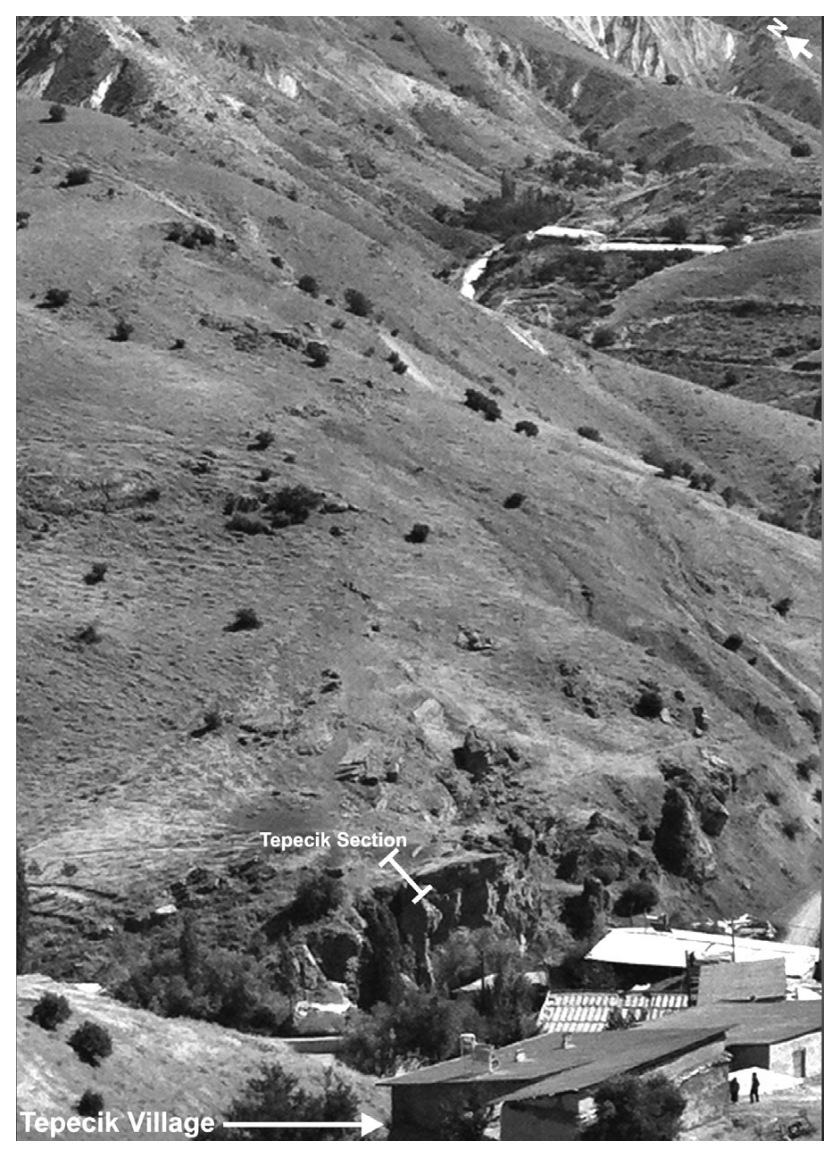

Figure 3. General view of the Tepecik section to the northwestern of the village of Tepecik, SE Gürün (Turkey).

Kurtman \& Akkuș 1974; Aziz et al. 1982; Atabey 1993, 1996). Atabey (1993, 1996) distinguished a poorly fossiliferous siliciclastic-dolomitic lithology in the Gürün-SW Sivas area in which skeletal limestones predominate.

The Tepecik section shows a thick Middle-Upper Devonian to Permian sequence situated about $500 \mathrm{~m}$ northwest of the village of Tepecik (Figs 2, 3). The lower part of the section comprises dark grey limestones, silty limestones and dark argillaceous fosiliferous shales referred to the Gümüșali Formation (Fig. 2B).

A second locality (Fig. 1) for examining the Middle-Upper Devonian is located $1.5 \mathrm{~km} \mathrm{SW}$ of Zincirkıran (sheet Van-Bașkale-H 38 1:100,000) in the upper part of the Ziyarettepe Formation (Fig. 1D) where $40 \mathrm{~m}$ of skeletal (brachiopods, crinoids, etc.) limestones, overlain by shale and clayey limestones, are exposed (Șenel 1987). Hitherto, only a few reports on the occurrence of skeletal remains in the Devonian of Turkey-Iran boundary were published. The Devonian outcrops in this area were first examined by Zahn (1906) and later several papers were published between 1906 and 1987 (e.g. Ortyniski 1944, Kiraner 1959, Șenel 1987). The pres- ence of local Devonian rocks in the Turkey-Iran boundary about $10 \mathrm{~km} \mathrm{SW}$ of the Van-Saray area has long been known (Kiraner 1959, Șenel et al. 1984). This easily accessible section on the road from Zincirkıran to Çardak has been studied by Kiraner (1959) and Șenel (1987). On the basis of tabulate corals, the Ziyarettepe Formation is said to be Middle-Upper Devonian (Șenel et al. 1984, Șenel 1987).

The Upper Devonian part (9 m) of the Tepecik section has yielded brachiopod representatives of various orders (Craniida, Strophomenida, Orthida, Productida, Atrypida, Athyridida, Spiriferida and Spiriferinida). The number of available specimens is reduced but the diversity is relatively high, suggesting that additional sampling would help to improve the precision on age and environmental conditions for these deposits. Fifteen brachiopod species and three crinoid species have been identified, two of them are new (Paillettia menae sp. nov. and Eodmitria sezgini sp. nov.). Five species identified in the Tepecik section are also present in the Zincirkıran section, and the 3 crinoid species are common to both localities. Noticeable is the lack of Rhynchonellida in these assemblages whereas they are generally well represented in strata of this period and constitute a key element for fine dating. Additional fauna includes Stromatopora sp., solitary rugose corals, Thamnopora sp., bryozoans, tentaculitids and gastropods.

\section{Systematic paleontology (R.G.)}

The material is housed in the Laboratoire de Paléontologie de Brest (LPB), Université de Bretagne Occidentale, France.

Abbreviations used in the descriptions. - L - length measured from the hinge to the anterior commissure; $\mathrm{L}_{\mathrm{t}}$ - total length including the beak; $\mathrm{W}$ - width; $\mathrm{W}_{\mathrm{s}}$ - width of the sulcus or fold at the anterior commissure; $\mathrm{H}_{\mathrm{d}}$ and $\mathrm{H}_{\mathrm{v}}-$ height (i.e. depth) of the dorsal and ventral valves respectively; $\mathrm{H}$ - total height (i.e. thickness) of the shell; $\mathrm{Nc}_{\mathrm{f}}$ and $\mathrm{Nc}_{\mathrm{s}}$ - number of ribs on one flank and sulcus or fold respectively.

\section{Brachiopoda}

Order Craniida Waagen, 1885

Superfamily Cranioidea Menke, 1828

Family Craniidae Menke, 1828

\section{Genus Petrocrania Raymond, 1911}

Type species. - Craniella meduanensis Oehlert, 1888. 
Petrocrania? sp.

Figure 5K

Material. - Tepecik section, level TR 5, LPB 19329, one dorsal valve.

Remarks. - This unique dorsal valve is mentioned here for information. It is very poorly preserved, the central part of the shell being broken. The shell is punctate, conical, subcircular, with a diameter of about $12 \mathrm{~mm}$. Concentric growth lines are numerous, regularly and closely spaced. The shell is fixed on a Douvillina shell of which it mimics the external radial ornament. Muscle scars not observed.

The type species of the genus was defined in the Lower Devonian of the Armorican Massif, France, in the Mayenne department (hence the name of the species) and not in the Ferques area, as erroneously mentioned in some recent publications. The genus is reported from the Ordovician to the Lower Carboniferous worldwide.

Order Strophomenida Öpik, 1934

Superfamily Strophomenoidea King, 1846

Family Douvillinidae Caster, 1939

Subfamily Douvillininae Caster, 1939

\section{Genus Douvillina Oehlert, 1887}

Type species. - Orthis dutertrei Murchison, 1840.

\section{Douvillina cedulae (Rigaux, 1872)}

Figure 4A-J

* 1872 Leptaena Cedulae; Rigaux, pp. 12, 15, pl. 1, fig. 9a, b.

Material. - Tepecik section, levels TR 1 (fragments), TR 2 (4 ventral valves), TR 4 (3 ventral, 1 dorsal valves and fragments), TR 5 (2 articulated shells), TR 6 (2 articulated shells and 1 ventral valve), LPB 19303, 19307, 19310, 19313, 19314, 19328, 19329, 19354-19356.

Description. - Pseudopunctate, strongly concavo-convex shell of moderate size (means: $\mathrm{L}=18.8 \mathrm{~mm}, \mathrm{~W}=21.8 \mathrm{~mm}$, $\mathrm{W} / \mathrm{L}=1.2 \mathrm{~mm}$ ). The shell is thin in its anterior part, much thicker in the posterior area. Width located at the hinge or slightly anterior to it. Most of the available shells have broken cardinal extremities, making this character difficult to appreciate, but after the aspect of the growth lines small mucronate extremities may have been present in some specimens. Geniculation lacking. Ventral area high with strongly marked vertical lines. Denticles strong. Narrow triangular delthyrium almost completely closed by a convex deltidium.

Dorsal interarea poorly developed. Triangular notothyrium closed by chilidium.
Relatively strong costellae, increasing by intercalation. New costellae slightly narrower than older ones but rapidly becoming of equal strength. The difference is more accentuated in juvenile stage (alternating fine and strong costellae giving a "Douvillina-type interstriate" ornament that fades in adult stage). There are about 13 costellae per $5 \mathrm{~mm}$ at $10 \mathrm{~mm}$ from the beak (i.e. 75 costellae). Very fine, closely spaced growth lines and rare, irregularly spaced growth lamellae, more expressed near the commissure.

Strong apical thickening in both valves resulting in a very low visceral cavity. Internal surface of both valves covered by densely distributed endospines. Transverse, semi-circular ventral muscle field deeply impressed, particularly in its median part, laterally well delimited by bounding ridges antero-laterally prolonged by a distinctive thin rim delimiting the entire periphery of the muscle field; it is longitudinally divided by a well-marked myophragm that abruptly ends on the edge of the muscle field. Dorsal interior with thick, low myophragm divided in side septa diverging anteriorly and giving rise to a median cavity. Cardinal process badly preserved, apparently consisting of two stout erect lobes.

The characters of this material allow an assignment to Douvillina Oehlert, 1887. Externally, this genus is very close to Strophodonta Hall, 1850, but in the latter the ventral muscle field is not well delimited as it is the case here, and the dorsal interior is different. The overall shape, size and ornament of our specimens are consistent with those of D. cedulae (Rigaux, 1872). A closely related species, D. dutertrei (Murchison, 1840), is often geniculate and shows small mucros that are not clearly expressed in our material. The same applies for D. ferquensis (Rigaux, 1872) that otherwise displays a smaller size and less numerous, stronger costellae. Douvillina area Mottequin, 2008 is larger, with much more developed interareas.

D. cedulae is reported from upper Givetian to lower Frasnian strata from France, Belgium and Spain (asymmetricus conodont Zone).

Sufamily Leptodontellinae Williams, 1965

\section{Leptodontellinae? indet.}

Figure 4L-P

Material. - Tepecik section, levels TR 1 (2 ventral valves and a fragment of juvenile specimen) and TR 4 ? (fragmentary ventral valve?), LPB 19303, 19313.

Description. - Rare, fragmentary specimens of medium size $\left(\mathrm{L}_{\max } \approx 24 \mathrm{~mm}, \mathrm{~W}_{\max } \approx 24 \mathrm{~mm}\right)$ present a transverse, sub-trapezoidal outline and a strongly geniculate profile. The width is located at the hinge, the angle of the latter with the lateral commissure is about $70^{\circ}$; small mucros are 


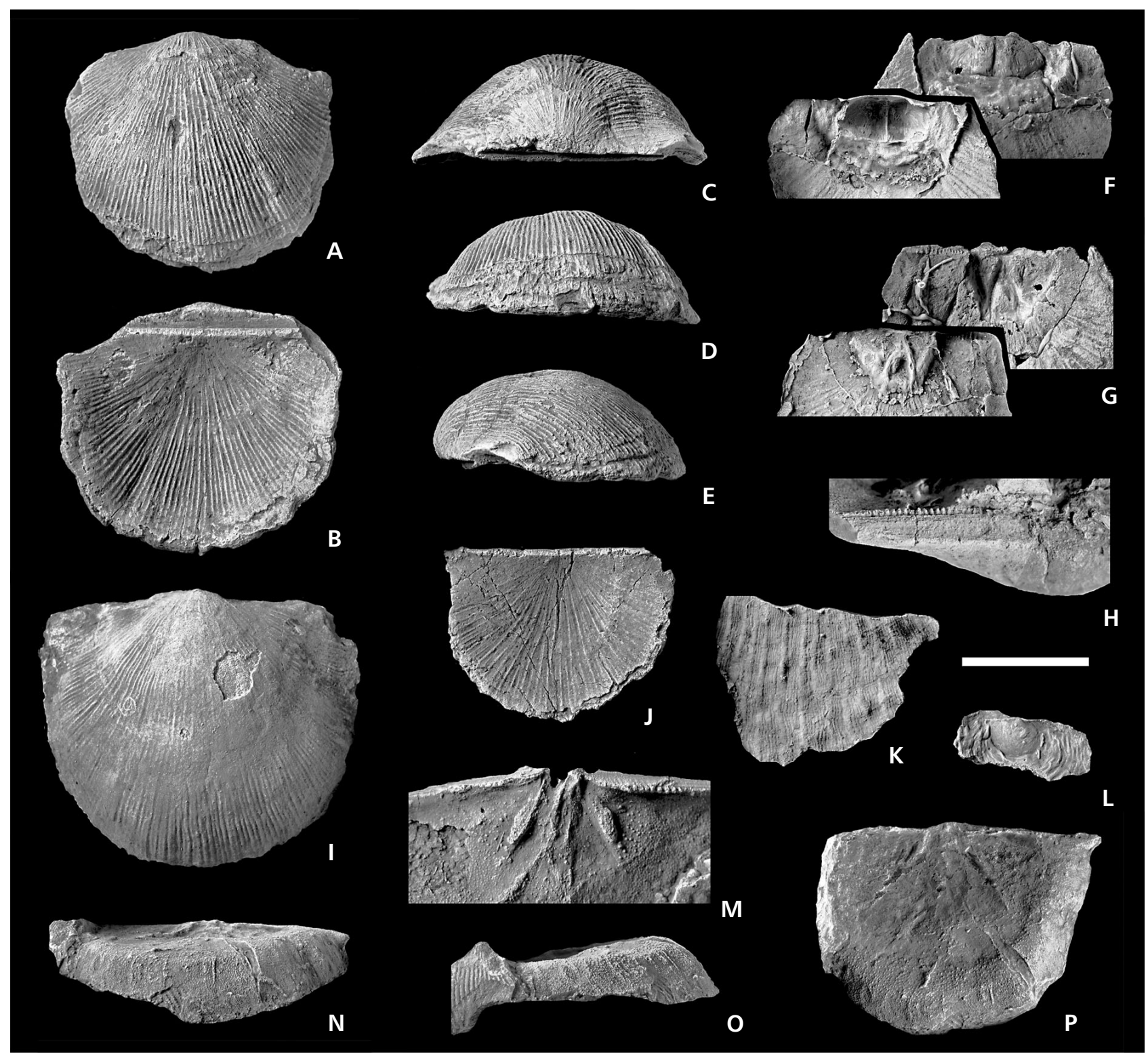

Figure 4. A-I - Douvillina cedulae (Rigaux, 1872); A-E - ventral, dorsal, posterior and lateral views of specimen LPB 19355, Tepecik section, level Tr6; F, G - ventral and dorsal interiors of a partially exfoliated shell and their latex counterpart, LPB 19354, Tepecik section, level Tr6; H - detail of the interarea showing crenulations, LPB 19356, Tepecik section, level Tr6; I - ventral valve, LPB 19307a, Tepecik section, level Tr2; J - dorsal valve, LPB 19313a, Tepecik section, level Tr4. $\bullet \mathrm{K}$ - Nervostrophia sp.; detail of the ornament showing irregular costellae, LPB 19311d, Tepecik section, level Tr3. • L-P - Leptodontellinae? ind.; Tepecik section, level Tr1; L - fragment of a juvenile shell showing rugae, LPB 19303u; M - ventral interior, LPB 19303o; N-P - ventral valve, anterior, lateral and dorsal views, LPB 19303t. Scale bar $=1 \mathrm{~cm}$, except for H, K, M: scale bar $=0.5 \mathrm{~cm}$.

present on one specimen. The frontal commissure is wide (about $1 / 2 \mathrm{~W}$ ) and parallel to the hinge line, lacking noticeable indentation. Rugae are present on the shell surface, excepted on the immediate vicinity of the apex. Denticles are present on the entire hinge.

The interior shell surface of the ventral valve is covered with endospines more or less radially arranged; the poorly impressed ventral muscle field is bounded by straight ridges that build an angle of about $60^{\circ}$; a low median septal ridge is apparently present, but this character could be an artifact due to the preservation of the (broken) specimen. Dorsal interior unknown.

Discussion. - The fragmentary material and the lack of information on the dorsal valve make a generic assignment difficult for this form that presents affinities with Leptaeninae (sharp geniculation, well developed concentric rugae). Nevertheless, the presence of denticles is not consistent 
with an assignment to this subfamily. The ventral interior evokes that of the Leptostrophiidae although the muscle field is not deeply impressed and does not seem to be partitioned by radial ridges; on the other hand, rugae are uncommon in Leptostrophiidae and it is the main distinctive character that allows a separation of this material from Nervostrophia sp. (cf. infra). Finally, a possible receptacle could be the subfamily Leptodontellinae although the bilobed character of the ventral muscle field appears to be lacking in our material.

Family Leptostrophiidae Caster, 1939

Genus Nervostrophia Caster, 1939

Type species. - Strophomena nervosa Hall, 1843.

\section{Nervostrophia sp.}

Figure 4K

Material. - Tepecik section, level TR 3 (fragmentary ventral valves with ornament), LPB 19311.

Remarks. - This material is represented only by a few shell fragments. The largest one is a relatively large broken ventral valve ( $\mathrm{L}$ and $\mathrm{W}$ probably $>30 \mathrm{~mm}$ ); the shell is pseudopunctate, with discontinuous, irregular, locally slightly sinuous costellae and finer (about 12 per $\mathrm{mm}$ ) sinuous costellae between the former. Endospines present. Interior unknown. Despite the rarity and poor quality of the specimens at hand, their ornament leaves little doubt about their affiliation to the genus Nervostrophia Caster, 1939. It is possible that some interiors assigned to Leptodontellinae indet. (see above) or some indeterminate "strophomenid" remains from others levels may belong to the present species, extending its vertical distribution in the section, but this would need further verification with new samplings allowing the study of both internal and external characters.

The type species of the genus, Nervostrophia nervosa (Hall, 1843), is known in the Frasnian of North America (New York, Pennsylvania and Virginia). The genus is also reported from deposits of possible Givetian age (North America, China) and Lower Famennian age (Northern France).

Order Orthida Schuchert \& Cooper, 1932

Superfamily Dalmanelloidea Schuchert, 1913

Family Rhipidomellidae Schuchert, 1913

\section{Genus Aulacella Schuchert \& Cooper, 1931}

Type species. - Orthis eifliensis Schnur, 1854 (= O. eifeliensis Verneuil, 1850, nom. nudum).
Aulacella eifliensis? (Schnur, 1853)

Figure 5I, J

* 1854 Orth. Eifliensis de Vern.; Schnur, p. 213, pl. 37, fig. $6 a-c$.

Material. - Tepecik section, levels TR 1 (1 dorsal valve and fragments), TR 2 (fragments), TR 4 (1 ventral valve), TR 5 (1 dorsal valve), LPB 19302, 19303, 19307, 19310, 19313, 19327. Zincirkıran section, CRN1, LPB 19300.

Description. - Punctate, moderately gibbose, apparently equibiconvex shell with subquadrate outline (means: $\mathrm{L}=$ $12.6 \mathrm{~mm}, \mathrm{~W}=15.4 \mathrm{~mm}, \mathrm{~W} / \mathrm{L}=1.2 \mathrm{~mm}$ ). Densely distributed punctae. Cardinal extremities subrounded. Ventral and dorsal interareas low and short. Lateral commissure curved, anterior commissure uniplicate. Width located about midlength. Median sulcus wide, well delimited but shallow in the dorsal valve, beginning near the beak. Ventral fold very low, poorly delimited.

Fascicostellate ornament; costellae numerous (10 to 13 costellae per $5 \mathrm{~mm}$ near the commissure), separated by wide interspaces. New costellae appear randomly on the shell surface. Growth lines are rare, irregularly distributed. Contrary to the flanks, the new costellae in the sulcus appear symmetrically.

Interior unknown.

Discussion. - In absence of information on internal features, this form is assigned to A. eifliensis (Schnur, 1853) with doubt. The external aspect is consistent with such an assignment, but further investigations are necessary. The species is known from the Eifelian to the Frasnian in Western Europe, Afghanistan and Russia.

Order Productida Sarytcheva \& Sokolskaya, 1959

Suborder Chonetidina Muir-Wood, 1955

Superfamily Chonetoidea Bronn, 1862

Family Anopliidae Muir-Wood, 1962

Subfamily Holynetinae Racheboeuf, 1981

Genus Holynetes Havlíček \& Racheboeuf, 1979

Type species. - Holynetes holynensis Havlíček \& Racheboeuf, 1979.

Holynetes? sp.

Figure 5L-P

Material. - Tepecik section, levels TR 4 (4 ventral valves), TR 5 (1 articulated shell), LPB 19313, 19314, 19326. Zincirkıran section, CRN1, LPB 19300. 


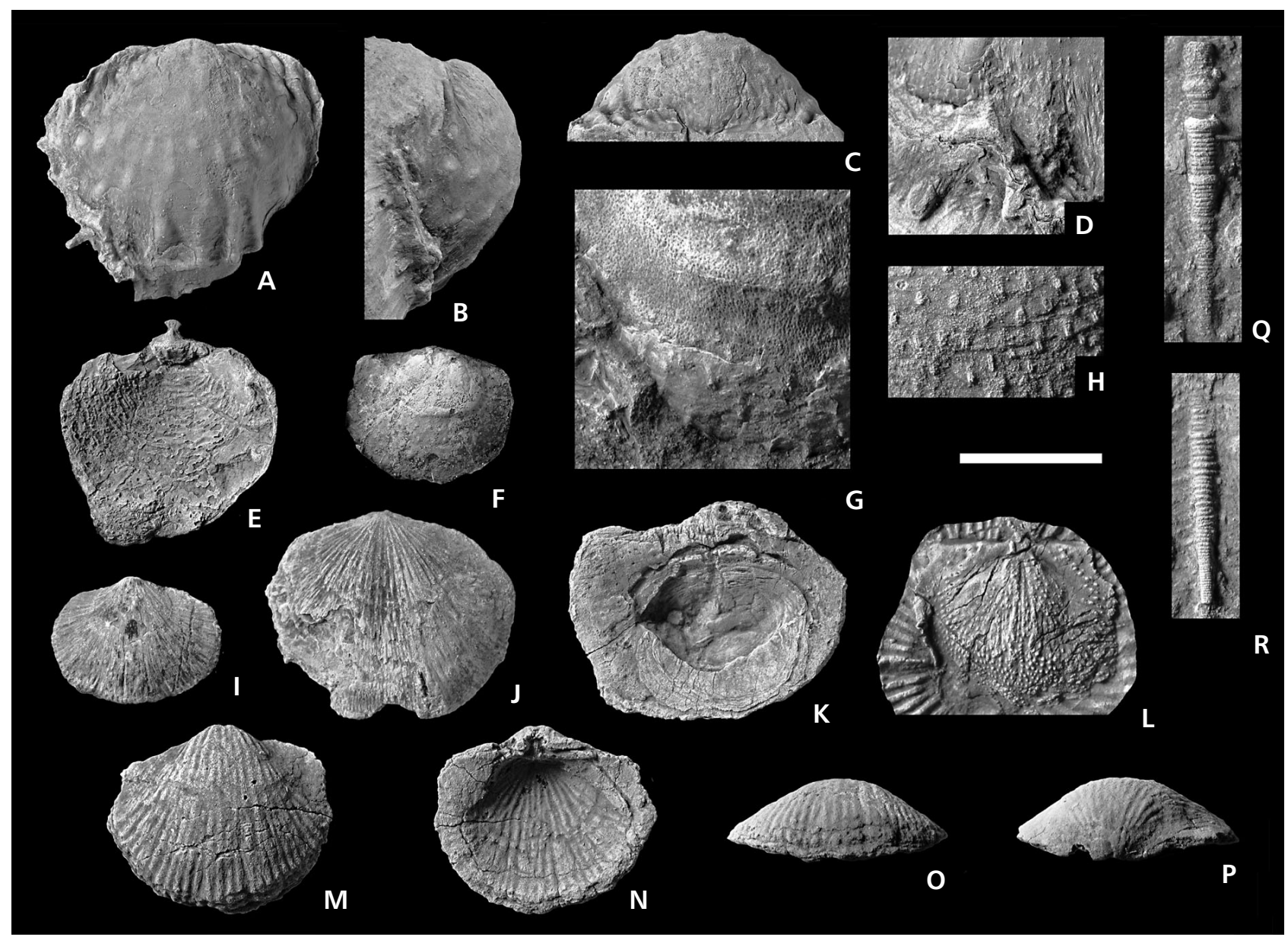

Figure 5. A-H - Spinulicosta spinulicosta (Hall, 1857); A-C - ventral, lateral and posterior views, LPB 19344, Tepecik section, level Tr6; D - the same, detail of ornament showing a large hollow spine (bottom, left) and microspines (right); E - dorsal valve, LPB 19297a, Zincirkıran section; F - latex replica of the external mold of a juvenile ventral valve, LPB 19310p, Tepecik section, level Tr2; G - partially exfoliated shell showing the endopunctae and micro-ornament, LPB 19310f, Tepecik section, level Tr2; H - detail of the spinose ornament, LPB 19303k, Tepecik section, level Tr1. - I, J - Aulacella eifliensis? (Schnur, 1853); I - ventral valve, LPB 19313p, Tepecik section, level Tr4; J - dorsal valve, LPB 19327, Tepecik section, level Tr5. • K - Petrocrania? sp.; broken valve attached on a specimen of Douvillina cedulae, LPB 19329, Tepecik section, level Tr5. $\bullet$ L-P - Holynetes? sp.; L - interior of a ventral valve, LPB 19313d, Tepecik section, level Tr4; M-P - ventral, dorsal, anterior and posterior views, LPB 19326, Tepecik section, level Tr5. • Q, R - undetermined tentaculitids, Tepecik section; Q - specimen LPB 19303h, level Tr1; R - specimen LPB 19313k, level Tr4. Scale bar $=0.5 \mathrm{~cm}$, except for A-C, F, K: scale bar $=1 \mathrm{~cm}$.

Description. - Concavo-convex shell with sub-circular outline. Width slightly anterior to hinge line. Costae wide, low, separated by narrow interspaces. There are around 35 costae near the commissure. New costae increasing by bifurcation (?).

Wide mantle cavity occupying about $2 / 3$ of the ventral interior. Endospines numerous and well developed in the anterior part of the shell. Vascula media well impressed, giving a neat median depression on internal molds and visible on $4 / 5$ of length. No median septum.

Dorsal interior unknown.

Discussion. - The scarcity of the material and the lack of dorsal valves do not allow a precise assignment. The characteristics observed on these specimens evoke
Holynetes holynensis Havlíček \& Racheboeuf, 1979 but further material, particularly dorsal interiors, is necessary to establish the presence of the genus in the studied area. The type species is known in the Middle Devonian (Eifelian) of France, Germany, Spain and Bohemia.

Suborder Productidina Waagen, 1883

Superfamily Productoidea Gray, 1840

Family Productellidae Schuchert, 1929

\section{Genus Spinulicosta Nalivkin, 1937}

Type species. - Productus spinulicostce Hall, 1857. 
Spinulicosta spinulicosta (Hall, 1857)

Figure 5A-H

* 1857 Productus spinulicostce (n. s.); Hall, p. 173.

Material. - Tepecik section, levels TR1 (2 ventral valves and fragments), TR2 (10 ventral, 2 dorsal valves and fragments), TR4 (1 ventral interior), TR 6 (1 ventral valve), LPB 19303, 19310, 19313, 19344. Zincirkıran section, CRN1 (1 dorsal, 2 ventral valves), LPB 19297.

Description. - Shell small (means: $\mathrm{L}=15.4 \mathrm{~mm}, \mathrm{~W}=$ $19.6 \mathrm{~mm}$ ) and slightly transverse (mean $\mathrm{W} / \mathrm{L}=1.3 \mathrm{~mm}$ ). Ventral valve strongly convex, dorsal valve concave. Width located anterior to hinge line. No ears observed. Interareas of both valves linear. The trail is lacking or poorly developed. "Ribs" rare, present only in the vicinity of the commissure of the ventral valve, lacking posteriorly. Rugae slightly sinuous, present only near the cardinal extremities and the postero-lateral area of the ventral valve. They start near the beak and are well marked. On the dorsal valve they are more pronounced, covering the entire surface of the valve, giving a dimpled aspect.

The ornament consists of very fine, closely distributed growth lines (about 6 per $1 \mathrm{~mm}$ ) and spines on the ventral valve. Two types of spines can be observed: 1) very fine micro-spines, the bases of which are initially very small, more or less rounded, very densely distributed in the posterior part of the shell and become more elongate (up to $0.5 \mathrm{~mm}$ long) towards the anterior commissure; 2) macro-spines, hollow near the anterior margin, apparently sealed in the posterior part of the shell, widely spaced and randomly distributed on the entire shell surface. Spine bases are clearly elongated posteriorly, character becoming more and more accentuated during shell growth and it is those aligned spine bases that constitute the "ribs" present on the anterior part of the shell. The basal part of a broken spine preserved at the commissure of a ventral valve is $3 \mathrm{~mm}$ long (Fig. 5D). Spines are absent on the dorsal valve.

The internal surface of the ventral valve is covered by small, densely distributed endospines.

In the dorsal valve, the cardinal process is erect normally to shell and longitudinally striated in its distal part that is slightly widening resulting in a more or less spatulate shape.

Discussion. - This form is assigned to Spinulicosta Nalivkin, 1937 rather than Productella Hall, 1867, due to the presence of elongate spine bases giving a ribbed aspect to the anterior part of the ventral valve, relatively strong rugae postero-laterally and a dimpled dorsal valve. In Helaspis Imbrie, 1959, the ribs start from the posterior part of the shell. The simultaneous presence of micro-spines and
Table 1. Biometric data for Kyrtatrypa sp. Legend for tables 1 to 3: $\mathrm{L}$ - length (from interarea to commissure); $\mathrm{L}_{\mathrm{t}}-$ total length (from umbo to commissure); $\mathrm{W}$ - width; $\mathrm{W}_{\mathrm{s}}$ - sulcus width; $\mathrm{W}_{2}$ - width between the $2^{\text {nd }}$ pair of ribs at the commissure; $\mathrm{H}_{\mathrm{d}}$ - height (thickness) of dorsal valve; $\mathrm{H}_{\mathrm{v}}$ - height (thickness) of ventral valve; $\mathrm{N}_{\mathrm{c}}$ - number of ribs; $\mathrm{Nc}_{\mathrm{f}}-$ number of ribs per flank; $\mathrm{Nc}_{\mathrm{s}}-$ number of ribs in the sulcus. The star indicates the holotype.

\begin{tabular}{llllll}
\hline Sample & $\mathrm{L}_{\mathrm{t}}$ & $\mathrm{W}$ & $\mathrm{H}_{\mathrm{d}}$ & $\mathrm{H}_{\mathrm{v}}$ & $\mathrm{Nc}$ \\
\hline LPB 19322 & 14 & 14 & 2.5 & 2.5 & 30 \\
LPB 19323 & 16 & 15.5 & 4.5 & 3 & 42 \\
LPB 19324 & 19 & 20 & 5.5 & 3 & 43 \\
LPB 19325 & 14.5 & 20 & 4.5 & 3.5 & 38 \\
LPB 19346 & 16.5 & 16 & 5.5 & 3 & 41 \\
LPB 19347 & 15 & 17 & 6 & 3.5 & 44 \\
LPB 19348 & 17 & 19 & 5 & 3.5 & 51 \\
LPB 19349 & 18.5 & 20 & 5.5 & 2.5 & 42 \\
LPB 19350 & 20 & 19 & 6.5 & 3 & 44 \\
LPB 19351 & 22.5 & 23 & 10 & 5 & 56 \\
LPB 19352 & 24.5 & 26 & 7 & 3.5 & 52 \\
LPB 19353 & 27 & 25 & 8 & 3.5 & 40 \\
\hline Mean & 18.7 & 19.5 & 5.9 & 3.3 & 44 \\
\hline
\end{tabular}

macro-spines has been reported by Hall (1857, p. 173) in the description of "Productus spinulicostae", type species of the genus. Spinulicosta navicella (Hall, 1857) differs of S. spinulicosta by its small size and a more elongate shell. Spinulicosta muirwoodi Johnson, 1971 and S. stainbrooki Crickmay, 1960 have more pronounced radial ornament and S. prima Chatterton \& Perry, 1978 has more numerous spines and irregular concentric rugae.

Spinulicosta spinulicosta is a widely distributed element of the Lower and Middle Devonian faunas but it has been also locally reported from younger strata (e.g. lower Frasnian of Viet Nam).

Order Atrypida Rzhonsnitskaia, 1960

Superfamily Atrypoidea Gill, 1871

Family Atrypidae Gill, 1871

\section{Genus Kyrtatrypa Struve, 1966}

Type species. - Atrypa (Kyrtatrypa) culminigera Struve, 1966.

\section{Kyrtatrypa sp.}

Figure 6A-N, Table 1

Material. - Tepecik section, levels TR 1 (1 ventral valve and fragments), TR 2 (1 articulated shell), TR4 (2 ventral valves), TR 5 (4 articulated shells), TR 6 (9 articulated shells), LPB 19301, 19302, 19304, 19313, 19322-19325, 19345-19353. 


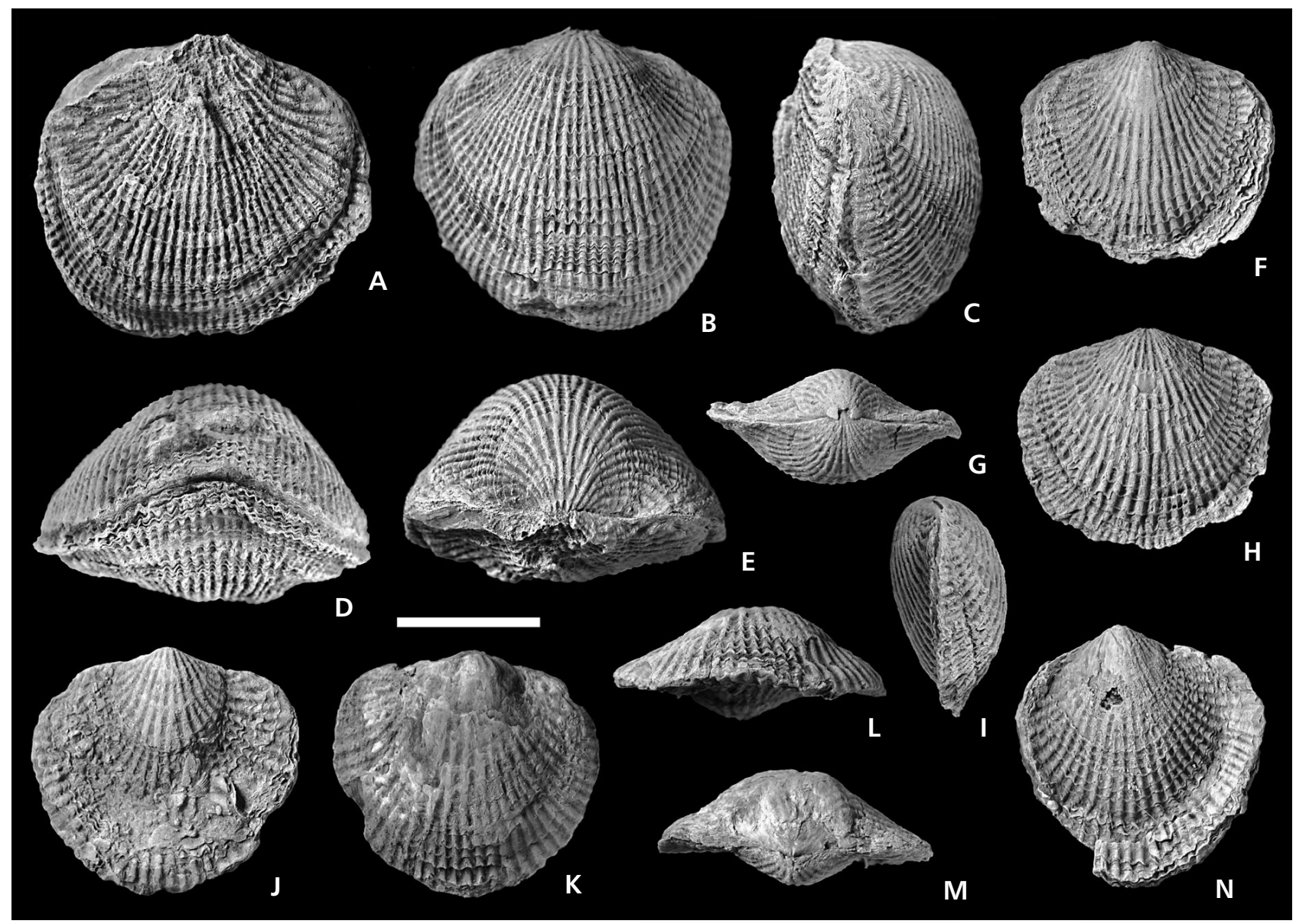

Figure 6. A-N-Kyrtatrypa sp.; A-E: ventral, dorsal, lateral, anterior and posterior views of a particularly gibbous specimen, LPB 19351, Tepecik section, level Tr6; F-I - ventral, posterior, dorsal and lateral views, LPB 19349, Tepecik section, level Tr6; J-M - ventral, dorsal, anterior and posterior views, LPB 19348, Tepecik section, level Tr6; N: ventral view, LPB 19324, Tepecik section, level Tr5. Scale bar $=1 \mathrm{~cm}$.

Description. - Dorsi-biconvex shell (mean $\mathrm{H}_{\mathrm{d}} / \mathrm{H}_{\mathrm{v}}=1.8$ ) of medium size (means: $\mathrm{L}=18.7 \mathrm{~mm}, \mathrm{~W}=19.5 \mathrm{~mm}$ ) with variable, from slightly transverse to subquadrate or slightly elongate outline (W/L varying from 0.9 to 1.4 , mean $=1.1$; Table 1). Hinge line narrower than maximum width that is located at about mid-length. Dorsal valve moderately to strongly curved (on adult specimens); ventral valve slightly curved, sometimes almost planar, but invariably curved or slightly carinate in the apical area. Fold and sulcus lacking. Rectimarginate to slightly uniplicate (adult specimens) commissure. Foramen rarely observed, apparently transapical.

Ribs numerous (mean $=44$ at $15 \mathrm{~mm}$ from the beak, that is 5-6 ribs for $5 \mathrm{~mm}$ at the commissure), narrow, increasing generally by intercalation, more rarely by bifurcation (specimens from level TR 5). Growth lamellae frilly, numerous, short, more dense and superimposed near the commissure where they can expand to wide frills, and slightly elevated on their anterior edges. The growth lamellae do not develop marginal spines. Locally microfila may be observed on these lamellae.

Interior unknown.
Discussion. - The ornament of short wavelike growth lamellae lacking spines, the slightly carinate ventral valve, the small beak and obscure foramen are consistent with an assignment of this form to the subfamily Atrypinae and particularly the genus Kyrtatrypa Struve, 1966. Atrypa (Planatrypa) Struve, 1966 lacks anterior frills on the growth lamellae, Atryparia Copper, 1966 often shows a more elongate shell, coarser ribs with relatively wide growth lamellae and Desquamatia Alekseeva, 1960 generally has finer ribs and a uniplicate commissure.

Kyrtatrypa sp. is very reminiscent of $K$. culminigera Struve, 1966, type species of the genus (Eifelian of Germany, also reported in Eifelian-Givetian of Algeria), but differs by its smaller size, stronger (and less numerous) ribs and shorter growth lamellae. Nevertheless, in absence of well-preserved complete specimens and information on interior structures, this form is let in open nomenclature.

Kyrtatrypa is a worldwide distributed, although not frequent genus known from the Lochkovian to the Lower-Middle Frasnian. 


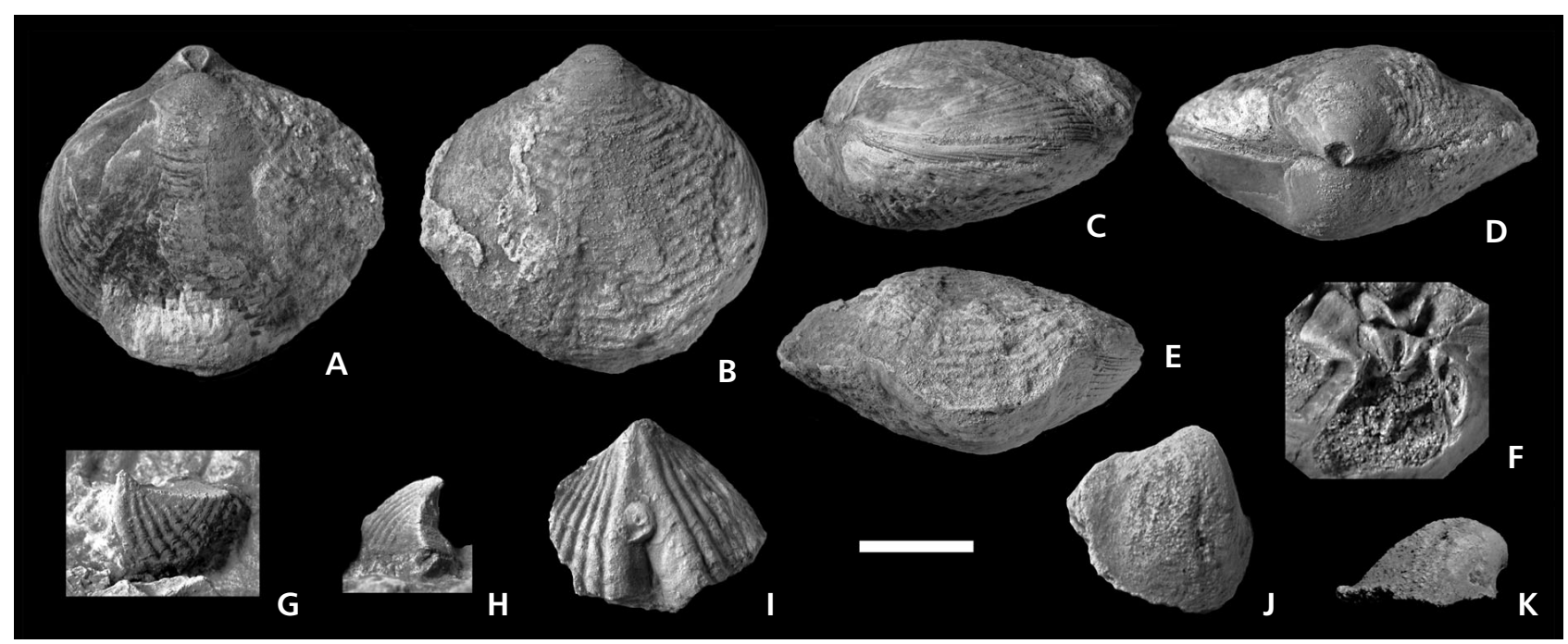

Figure 7. A-F-Cleiothyridina? sp.; A-E-dorsal, ventral, lateral, posterior and anterior views, LPB 19357, Tepecik section, level Tr6; F-detail of the apical structure on a partially exfoliated shell, LPB 19358, Tepecik section, level Tr6. • G-I - Cyrtina douvillei Rigaux, 1908; G, H - ventral and lateral views of a broken ventral valve, LPB 19302a, Tepecik section, level Tr1; I - antero-ventral view of a ventral valve, LPB 19303b, Tepecik section, level Tr1. •J, K - Ambocoeliid ind.; ventral and lateral views of specimen LPB 19308, Tepecik section, level Tr2. Scale bar = $0.5 \mathrm{~cm}$, except for F, J, K: scale bar $=0.25 \mathrm{~cm}$ and G-I: scale bar $=1 \mathrm{~cm}$.

Order Athyridida Boucot, Johnson \& Staton, 1964

Superfamily Athyridoidea Davidson, 1881

Family Athyrididae Davidson, 1881

\section{Genus Cleiothyridina Buckman, 1906}

Type species. - Atrypa pectinifera J. de C. Sowerby, 1840.

\section{Cleiothyridina? sp.}

Figure 7A-F

Material. - Tepecik section, levels TR 1 (2 ventral valves and fragments), TR 2 (3 ventral, 1 dorsal valves and fragments), TR 4 ( 2 ventral valves), TR 5 (1 articulated shell), TR 6 (1 articulated shell and 2 ventral valves), LPB 19303, 19308, 19313, 19330, 19357-19359. Zincirkıran section, CRN1, LPB 19300.

Description. - Shell of medium size, equidimensional (means: $\mathrm{L}=14.0 \mathrm{~mm}, \mathrm{~W}=15.5 \mathrm{~mm} ; \mathrm{W} / \mathrm{L}=1.1)$, biconvex, almost equibiconvex (mean $1 / \mathrm{L}=0.7$ ), feebly curved, entirely smooth. Sulcus and fold lacking or poorly expressed in the immediate vicinity of the anterior commissure. Tongue trapezoidal in cross section. Uniplicate anterior commissure. Massive, slightly prominent ventral beak with apical foramen.

Frilly, regularly spaced, numerous growth lamellae with anterior spiny (?) projections visible on a single specimen (wavy undulations on the frills of a ventral valve, level TR 5).

Ventral interior with short, narrow, divergent and oblique dental plates. Lateral apical cavities narrow.
In the dorsal valve, the inner hinge plates are thick. A myophragm (or septum?) is apparently present. Spiralium with about 10 whorls per cone.

Discussion. - Despite the poor preservation of this material that does not allow making a reliable opinion, the possible presence of spine-like extensions on the anterior edge of the growth lamellae and the poorly developed fold/sulcus allow to consider an assignment to Cleiothyridina Buckman, 1906. Our specimens are comparable in size to the type species (defined in the Humbleton Quarry, United Kingdom, Permian) but differ in their more rounded outline and their lower convexity. Cleiothyridina is a cosmopolitan genus known mainly from the Upper Devonian to the Permian, but earlier occurrence has been recorded in the Givetian of the Blacourt Formation (N. France): Cleiothyridina blacourti Brice, Mottequin \& Loones, 2009 differs of Cleiothyridina sp. by its larger size, its transverse outline and its higher, well differentiated fold and tongue.

Order Spiriferida Waagen, 1883

Suborder Spiriferidina Waagen, 1883

Superfamily Adolfioidea Sartenaer, 1966

Family Adolfiidae Sartenaer, 1966

Subfamily Adolfiinae Sartenaer, 1966

\section{Genus Paillettia García-Alcalde, 2005}

Type species. - Spirifer paillettii Verneuil, 1850. 
Table 2. Biometric data for Paillettia menae sp. nov. (for legend see Table 1).

\begin{tabular}{|c|c|c|c|c|c|c|c|c|c|c|c|}
\hline Sample & $\mathrm{L}$ & $\mathrm{L}_{\mathrm{t}}$ & W & $\mathrm{W}_{\mathrm{s}}$ & $\mathrm{W}_{2}$ & $\mathrm{H}_{\mathrm{d}}$ & $\mathrm{H}_{\mathrm{v}}$ & $\mathrm{Nc}_{\mathrm{f}}$ & $\mathrm{Nc}_{\mathrm{s}}$ & $\mathrm{W} / \mathrm{L}$ & $\mathrm{W}_{\mathrm{s}} / \mathrm{W}$ \\
\hline LPB 19303a & 11 & & 19 & 4.5 & 7 & 3.5 & & 7 & 3 & 1.7 & 0.2 \\
\hline LPB $19303 b$ & 13.5 & 16 & 15 & 5 & 8 & & 6 & 9 & 1 & 1.1 & 0.3 \\
\hline LPB $19341 *$ & 12 & 15 & 18 & 7 & 9 & 2 & 6 & 8 & 3 & 1.5 & 0.4 \\
\hline LPB 19342 & 9 & & 18 & 5 & 8 & 3.5 & 5 & 8 & 1 & 2.0 & 0.3 \\
\hline LPB 19343 & 18 & 11 & 20 & 6 & 9 & & 6 & 7 & 1 & 1.1 & 0.3 \\
\hline LPB 19297 & 10 & & 22 & 6 & 8.5 & 3 & & 7 & 1 & 1.6 & 0.3 \\
\hline Mean & 12.3 & 14.0 & 18.7 & 5.6 & 8.3 & 3.0 & 5.8 & 7.7 & 1 or 3 & 1.6 & 0.3 \\
\hline
\end{tabular}

Paillettia menae sp. nov.

Figure 8A-P, Table 2

? 1976 Tylothyris sp. - Lebküchner, p. 3.

Material. - Tepecik section, levels TR1 (2 ventral, 3 dorsal valves and fragments), TR4 (1 dorsal valve and fragments), TR 6 (2 articulated shells and 1 ventral valve), LPB 19303, 19313, 19341-19343. Zincirkıran section, CRN2 (1 dorsal interior), LPB 19297.

Etymology. - A species dedicated to Mena SchemmGregory, a German brachiopodologist who died prematurely in July 2013.

Holotype. - Slightly crushed, complete specimen LPB 19341 from level TR 6, Tepecik section.

Type locality and age. - Tepecik section, Gümüșali Formation, uppermost Givetian to lower Frasnian.

Diagnosis. - A relatively large species of Paillettia with a short anterior rostral extension and a pair of accessory lateral ribs that may occasionally develop on fold and sulcus.

Description. - Small ventribiconvex transverse shell (means: $\mathrm{L}=12.3 \mathrm{~mm}, \mathrm{~W}=18.7 \mathrm{~mm}$; W/L = 1.6; Table 2). Width located at the hinge line. Cardinal extremities acute to slightly mucronate. The rounded anterior outline is typically interrupted by the protrusion of the tongue. Ventral valve higher than dorsal one (mean $\mathrm{H}_{\mathrm{d}} / \mathrm{H}_{\mathrm{v}}=0.5$ ). Ventral interarea apsacline, almost flat but strongly curved under the beak that is strongly developed. The delthyrium is wide, triangular, and more or less equilateral.

Sulcus and fold are well delimited, moderately wide (mean $\mathrm{W}_{\mathrm{s}} / \mathrm{W}=0.3$ ). The sulcus is shallow, widely flared and bears a median angular rib that appears at the umbo. The fold is low, sub-carinate and also bears an angular median ridge initially poorly expressed in the posterior part of the shell but becoming strongly developed towards the anterior edge. These ventral and dorsal median ribs build a characteristic rostral protrusion (opposite folding) that expands beyond the anterior commissure on a short distance. On the holotype, the median sinal rib is flanked by two lateral ribs that appear in the vicinity of the beak and are initially stronger and higher than the median rib, then gradually vanishing toward anterior and finally disappearing near the commissure where only a strongly developed median rib is present; on the same specimen the fold is divided into three ribs a few millimeters from the beak, with an elevated angular median rib and two lower, rounded adjacent ribs, located on the flanks of the fold. Another isolated brachial valve shows similar characteristics.

Flanks bear relatively strong angular ribs separated by similar interspaces. There are about 8 ribs per flank.

The microornament consists of discrete, locally frilly, growth lines. They are crossed by coarse capillae with a pronounced pseudo-radial arrangement typical of the Adolfiidae (Fig. 8F).

The dental plates are thin, divergent, located on the second or third pair of ribs. Delthyrial plate or apical thickening lacking.

Figure 8. A-P-Paillettia menae sp. nov.; A-F - dorsal, ventral, anterior, posterior, lateral views and detail of the micro-ornament of the holotype; note the anterior rostral excrescence and the sinal ribs, LPB 19341, Tepecik section, level Tr6; G-K - dorsal, ventral, anterior, posterior and lateral views, LPB 19342, Tepecik section, level Tr6; L - ventral valve with acute cardinal extremities, LPB 19343, Tepecik section, level Tr6; M, N - dorsal and lateral views of a dorsal valve; note the rostral excrescence on N, LPB 19303a, Tepecik section, level Tr1; O, P - internal mould of a brachial valve and its latex replica, detail of the cardinalia, LPB 19297b, Zincirkıran section. • Q-T - Laudonomphalus sp. ex gr. L. ornatus-regularis, Zincirkıran section; Q - stem fragment showing the tubercles and faint keel of the lateral surface, LPB 19298a; R - articular facet, LPB 19293; S - articular facet, LPB 19294; T - articular facet, LPB 19296. • U, V - Paracyclocaudex sp.; U - articular facet, LPB 19303m, Tepecik section, level Tr1; V - articular facet, LPB 19300g, Zincirkiran section. • W-Y - Tantalocrinus sp.; W - articular facet, LPB 19301f, Tepecik section, level Tr1; X - articular facet, LPB 19300k, Zincirkıran section; Y - articular facet with cirral canal, LPB 19300h, Zincirkıran section. Scale bar = $1 \mathrm{~cm}$, except for F, O, P, W-Y: scale bar $=0.5 \mathrm{~cm}$. 


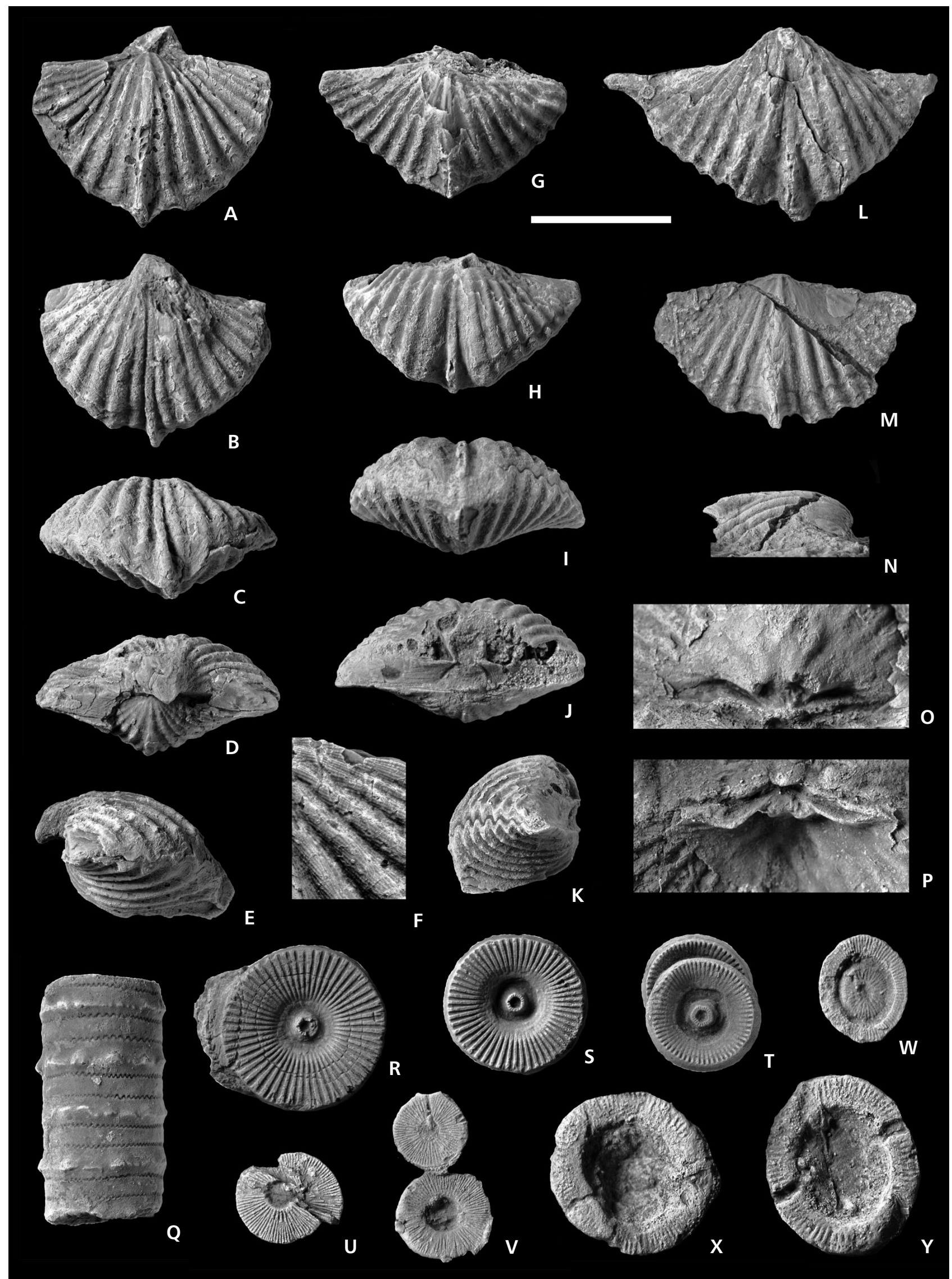


Ctenophoridium comprising about 10-12 lamellae, located on an elevated shelf as usual in many Adolfiidae. Crural plates tilted, well developed but not joining the valve floor or only in their very posterior part that is embedded in the shelf supporting the ctenophoridium. Sockets widely divergent, narrow, shallow and relatively short.

Discussion. - García-Alcalde (2005) includes in the genus two Spanish species, Paillettia paillettei (Verneuil, 1850) (Upper Emsian, type species), P. cancellata GarcíaAlcalde, 2005 (Upper Emsian), a single specimen probably erroneously identified as $P$. paillette $i$ by Heddebaut (1973) from the French Pyrenees (Upper Emsian), and P. foucauldi (Le Maître, 1952) from the lower Eifelian of Algeria, resulting in an Emsian-Eifelian range of the genus. Nevertheless, the assignment of P.? foucauldi to Paillettia is subject to caution, the species showing a low number of lateral ribs, the external ones being very faint, and a high ventral interarea. These characteristics are reminiscent of the genus Plicocyrtina Havlíček, 1956; so far, the internal features of Paillettia? foucauldi are unknown but should the presence of a ventral median septum be attested in the future, this species would rather be assigned to Plicocyrtina.

The features observed in our species, particularly the anterior outgrowth of the sinal/dorsal median rib (present although less developed than in the type species), the micro-ornament and the interior characteristics, are consistent with an assignment to Paillettia.

Paillettia menae sp. nov. differs of $P$. paillettei (Verneuil, 1850) by its larger size, its less developed anterior rostral expansion and a higher number of lateral ribs (only 4 to 6 ribs in $P$. paillettei). The accessory lateral ribs on sulcus and fold have never been observed in the type material of $P$. paillettei (García-Alcalde, pers. comm.). It differs from $P$. cancellata García-Alcalde, 2005 by its larger size, fewer lateral ribs, and a less developed median sinal rib that is always lower than sulcus-bounding ribs. Paillettia? foucauldi (Le Maître, 1952) is larger than $P$. menae sp. nov., has a fewer number of ribs, and shows a very high ventral interarea, giving to the shell a cyrtiniform aspect. Some species of Eleutherokomma Crickmay, 1950 with short mucros and sinal ridge may present a more or less similar aspect with $P$. menae sp. nov., but they differ in a flattened or furrowed fold, the lack of anterior rostral expansion and their finer micro-ornament. More generally, Eleutherokomma typically possess long to very long mucros (see for example E. monodi Gourvennec in Racheboeuf et al., 2004).

The genus was previously known from the Upper Emsian in Spain and southern France to possibly the lower Eifelian in Northern Africa (Algeria). Its range is now extended to the transitional Givetian/Frasnian period. Taking into account the similarities between the two genera (outline, type of macro-ornament, etc.) we can suspect that the mention of Tylothyris North, 1920 in the Devonian (with no more precision) of the Hazro area (Lebküchner 1976) possibly corresponds to Paillettia. In addition the accompanying fauna listed by this author is reminiscent of the fauna described herein. Lebküchner unfortunately gave only a list of species without descriptions so that at present any serious comparison with our material is impossible.

Genera possessing such a rostral anterior expansion are rare. They are sporadically reported at different periods in different unlinked superfamilies. This is probably an adaptation to very specific environmental conditions, likely an ecological niche because accompanying fauna does not exhibit particular morphological changes, as may be the case in environments with exceptional features (e.g. black shales), in which all components are affected by these modifications. The functional utility of such a rostral development, the length of which can exceed the shell length in Paillettia paillettei, remains an enigma.

Superfamily Cyrtospiriferoidea Termier \& Termier, 1949 Family Cyrtospiriferidae Termier \& Termier, 1949

\section{Genus Cyrtospirifer Nalivkin (in Fredericks), 1924}

Type species. - Spirifer verneuili Murchison, 1840.

\section{Cyrtospirifer sp. ex gr. C. verneuili (Murchison, 1840)} Figure 9A-U

Material. - Tepecik section, levels TR 1 (3 ventral valves), TR 2 (4 ventral, 1 dorsal valves and fragments), TR 3 (1 articulated shell, 9 ventral and 3 dorsal valves), TR 5 ( 1 articulated shell and 2 ventral valves), TR 6 (4 articulated crushed shells), LPB 19302?, 19303, 19305-19306, 19309-19312, 19315-19317, 19331-19334.

Description. - Medium to large shells (means: $\mathrm{L}=$ $14.2 \mathrm{~mm}, \mathrm{~W}=30.6 \mathrm{~mm}$ ), the largest (incomplete) shell being about $60 \mathrm{~mm}$ wide, moderately to distinctly transverse (mean $\mathrm{W} / \mathrm{L}=2.2$ ), width being located anterior to hinge. Cardinal extremities angular in outline. In some individuals, the shell is very transverse (W/L up to 2.7) with acute cardinal extremities and width located at the hinge line (level TR 6). The shell is entirely costate. The anterior commissure is feebly uniplicate. Ventral valve moderately convex. Ventral interarea regularly curved in longitudinal section, apsacline, sharply separated from flanks by an angular crest. In some cases it can be very elevated, more or less planar and curved only near the apex (levels TR 2 and TR6). It is vertically striated. The delthyrium is triangular, 


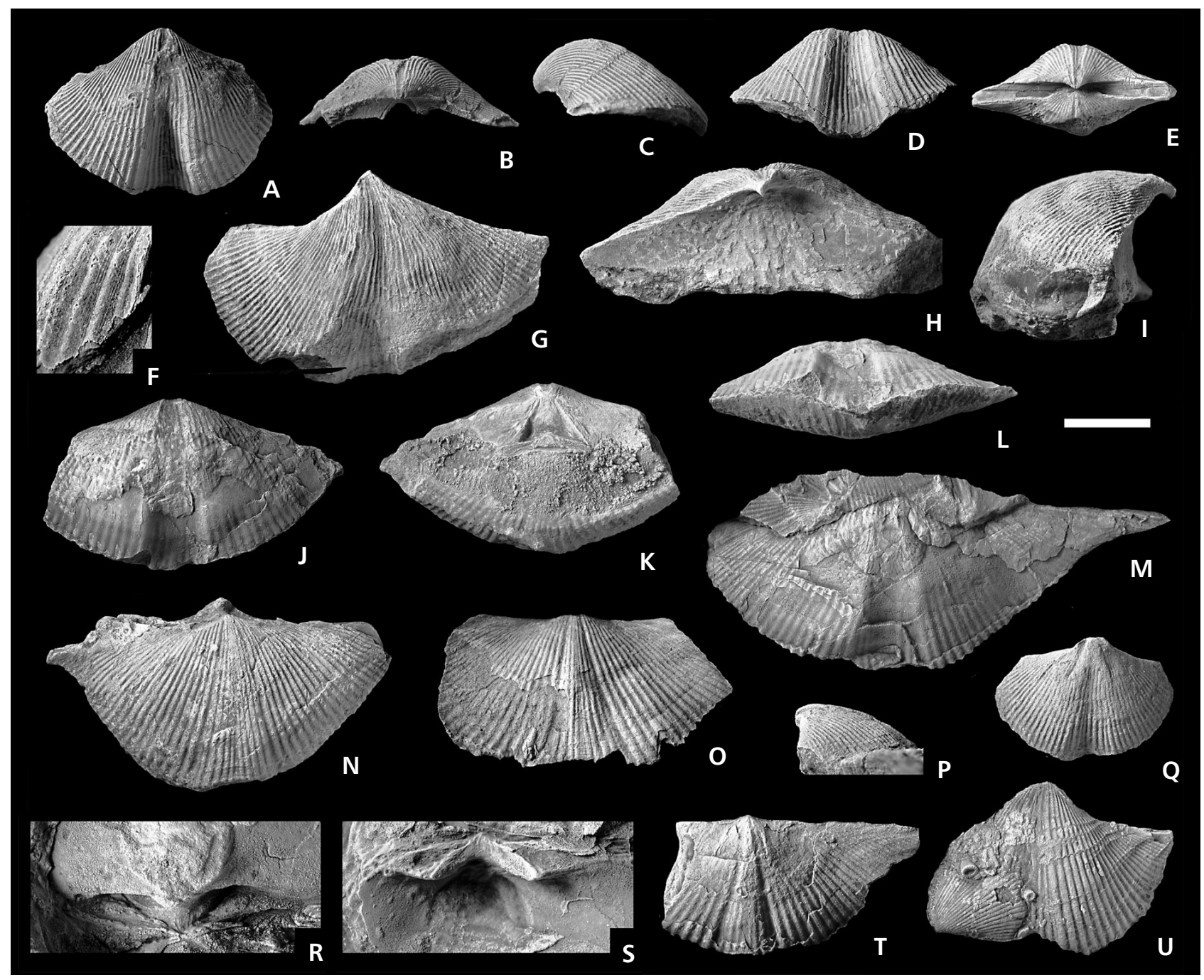

Figure 9. Cyrtospirifer sp. ex gr. C. verneuili (Murchison, 1840). A-D - ventral, posterior, lateral and anterior views of a ventral valve, LPB 19315 , Tepecik section, level Tr5. E - posterior view, LPB 19332, Tepecik section, level Tr6. • F - detail of ornament in the sulcus of specimen LPB 19333 , Tepecik section, level Tr6. - G-I - ventral, posterior and lateral views of a large distorted specimen, LPB 19305, Tepecik section, level Tr2. - J-L - ventral, dorsal and anterior views of a flattened specimen showing delthyrial plate and spiralium (K), LPB 19311, Tepecik section, level Tr3. - M - partially exfoliated ventral valve showing the excavated muscle field, LPB 19312e, Tepecik section, level Tr3. • N - dorsal valve, LPB 19331, Tepecik section, level Tr6. $\bullet$ O - latex replica of a dorsal valve, LPB 19312c, Tepecik section, level Tr3. $\bullet$ P-Q - lateral and ventral views of a ventral valve, LPB 19306, Tepecik section, level Tr2. $\bullet$ R, S - internal mould, detail of the cardinalia and its latex replica showing the ctenophoridium, sockets and muscle field, LPB 19312a, Tepecik section, level Tr3. • T - dorsal valve showing the well delimited fold and mucronate cardinal extremities, LPB 19312d, Tepecik section, level Tr3. • U - ventral valve, LPB 19303s, Tepecik section, level Tr1. Scale bar $=1 \mathrm{~cm}$, except for F: scale bar $=0.25 \mathrm{~cm}, \mathrm{R}-\mathrm{T}$ : scale $\mathrm{bar}=0.5 \mathrm{~cm}$.

relatively narrow at its base, entirely open. Hypodeltidial furrows and deltidial lamellae present. The beak is generally poorly prominent or occasionally strongly curved over the interarea (level TR 6).

Sulcus and fold well delimited (mean $\mathrm{W}_{\mathrm{s}} / \mathrm{W}=0.3$ ). The fold is low to very low, rounded, well limited by interspaces slightly but clearly wider and deeper than adjacent ones. The sulcus is moderately deep, with a rounded or $\mathrm{V}$-shaped section. Ribs present on sulcus and fold reproduce by bifurcation. First division occurs early, immediately near the umbo.
Ribs on the flanks are simple, rounded in section, separated by narrow rounded interspaces.

The microornament consists of densely distributed, feebly expressed, concentric growth lines. These are crossed by radial, feebly divergent capillae (TR6) bearing low abraded pustules.

Dental plates extrasinal, straight, reaching $1 / 3$ of shell length. Delthyrial plate well developed, reaching about half of the delthyrium height. Apical thickening present. The muscle field is strongly excavated.

The ctenophoridium is located on an elevated shelf or 
Table 3. Biometric data for Eodmitria sezgini sp. nov. (for legend see Table 1).

\begin{tabular}{|c|c|c|c|c|c|c|c|c|c|c|}
\hline Sample & $\mathrm{L}$ & $\mathrm{L}_{\mathrm{t}}$ & W & $\mathrm{W}_{\mathrm{s}}$ & $\mathrm{H}_{\mathrm{d}}$ & $\mathrm{H}_{\mathrm{v}}$ & $\mathrm{Nc}_{\mathrm{f}}$ & $\mathrm{Nc}_{\mathrm{s}}$ & $\mathrm{W} / \mathrm{L}$ & $\mathrm{W}_{\mathrm{s}} / \mathrm{W}$ \\
\hline LPB 19301a & 9 & 11.5 & 15 & 4 & & & 20 & 8 & 1.7 & 0.3 \\
\hline LPB 19302 & 9 & 10.5 & 13 & 3 & & & 16 & 8 & 1.4 & 0.2 \\
\hline LPB 19303b & 7.5 & 10 & 13 & 3.5 & & & 16 & 7 & 1.7 & 0.3 \\
\hline LPB $19318^{*}$ & 10.5 & 13.5 & 16 & 6 & 3 & 6 & 19 & 11 & 1.5 & 0.4 \\
\hline LPB 19319 & 9 & 10.5 & 11.5 & 4 & 2 & 5 & 18 & 7 & 1.3 & 0.3 \\
\hline LPB 19320 & 7.5 & 10.5 & 11.5 & 4 & & 4.5 & 17 & 9 & 1.5 & 0.3 \\
\hline LPB 19338 & 10.5 & & 16 & 4 & 3.5 & & 18 & 9 & 1.5 & 0.3 \\
\hline LPB 19335 & 8 & 10.5 & 14.5 & 3 & & 6 & 20 & 7 & 1.8 & 0.2 \\
\hline LPB 19336 & 9.5 & 11 & 15 & 4 & 2 & 5 & 22 & 8 & 1.6 & 0.3 \\
\hline LPB 19337 & 9 & 11 & 16 & 4.5 & 3.5 & 7 & 20 & & 1.8 & 0.3 \\
\hline LPB 19300a & 9 & 10.5 & 11.5 & 3.5 & & 4.5 & 18 & 9 & 1.3 & 0.3 \\
\hline LPB 19300b & 5 & 6 & 9 & 2.5 & & 2.5 & 18 & 8 & 1.8 & 0.3 \\
\hline LPB 19300c & 5.5 & 7 & 8 & 3 & & 3 & 15 & 10 & 1.5 & 0.4 \\
\hline LPB 19300d & 10 & 11 & 12 & 3 & & 4 & 22 & 9 & 1.2 & 0.3 \\
\hline LPB $19300 \mathrm{e}$ & 10 & 11.5 & 14.5 & 5 & & 4.5 & 22 & 11 & 1.5 & 0.3 \\
\hline LPB $19300 f$ & 9 & 11 & 14 & 4 & & 4 & 21 & 10 & 1.6 & 0.3 \\
\hline LPB 19290 & 4 & 5 & 6.5 & 1.5 & & 2 & 17 & 6 & 1.6 & 0.2 \\
\hline Mean & 8.4 & 10.1 & 12.8 & 3.7 & 2.8 & 4.5 & 18.8 & 8.6 & 1.5 & 0.3 \\
\hline
\end{tabular}

massive platform that extends anteriorly as a strong, short, massive myophragm that disappear more or less in the apical shell thickening on mature specimens. Crural plates are apparently lacking or hidden by apical thickening of the shell. Sockets are divergent, relatively shallow and rapidly widening forwards. Spiralium with at least 15 whorls per cone. Posterior adductor scars slightly impressed on the valve surface.

In the level TR2, one specimen is larger with finer, more numerous ribs (Fig. 9G-I) but, due to the scarcity of material, it is considered here as a local variant of the species.

Discussion. - The combination of characters in this form is unusual, and its assignment remains problematical. The overall shape of the shell, the well-delimited sulcus and fold, the ornament, the lack of crural bases and the presence of a delthyrial plate are consistent with an assignment to Cyrtospirifer Nalivkin, 1924. On the other hand, the weak development of the fold pleads against such an assignment and would rather favor an assignment to Eodmitria Brice, 1982, despite the transverse aspect of the shell of some specimens, the lack of flattened lateral ribs, the well delimited fold (adjacent interspaces wider and deeper than lateral ones) and the lack of crural plates. This illustrates the difficulties encountered in the characterization of the Cyrtospiriferids as mentioned by several authors in the recent years (e.g. Carter et al. 1994, Ma \& Day 2003, etc.) but the problem is much older and present from the $19^{\text {th }}$ century (Gosselet 1894). Cyrtospirifer is in need of revision; this taxon should therefore be used with caution. In particular, the nu- merous mentions of the type species $C$. verneuili are to be revisited. In their excellent review of systematic drifts undergone by the genus Cyrtospirifer, Ma \& Day (2003) have inventoried more than one hundred species and it would be futile here to compare our material to this disparate group. In the state of the art, the species $C$. verneuili is a possible receptacle for the Turkish specimens despite the aspect of the fold that is usually more developed in C. verneuili and the presence of an excavated ventral muscle field. Before a new species is erected from this material, it is necessary to obtain more specimens in order to establish the variation spectrum of the implicated characters. C. verneuili, described for the first time from the Frasnian of Ferques (Northern France), is cosmopolitan and reported from the upper Middle Devonian (Givetian) to the Upper Devonian (although Famennian occurrences are dubious).

\section{Genus Eodmitria Brice, 1982}

Type species. - Eodmitria supradisjuncta boloniensis Brice, 1982.

\section{Eodmitria sezgini sp. nov.}

Figure 10A-R, Table 3

Material. - Tepecik section, levels TR 1 (8 ventral, 4 dorsal valves and fragments), TR 2 (6 ventral, 1 dorsal valves), TR 4 (3 ventral, 2 dorsal valves and fragments), TR 5 (3 articulated shells and 1 ventral valve), TR 6 (1 articulated 


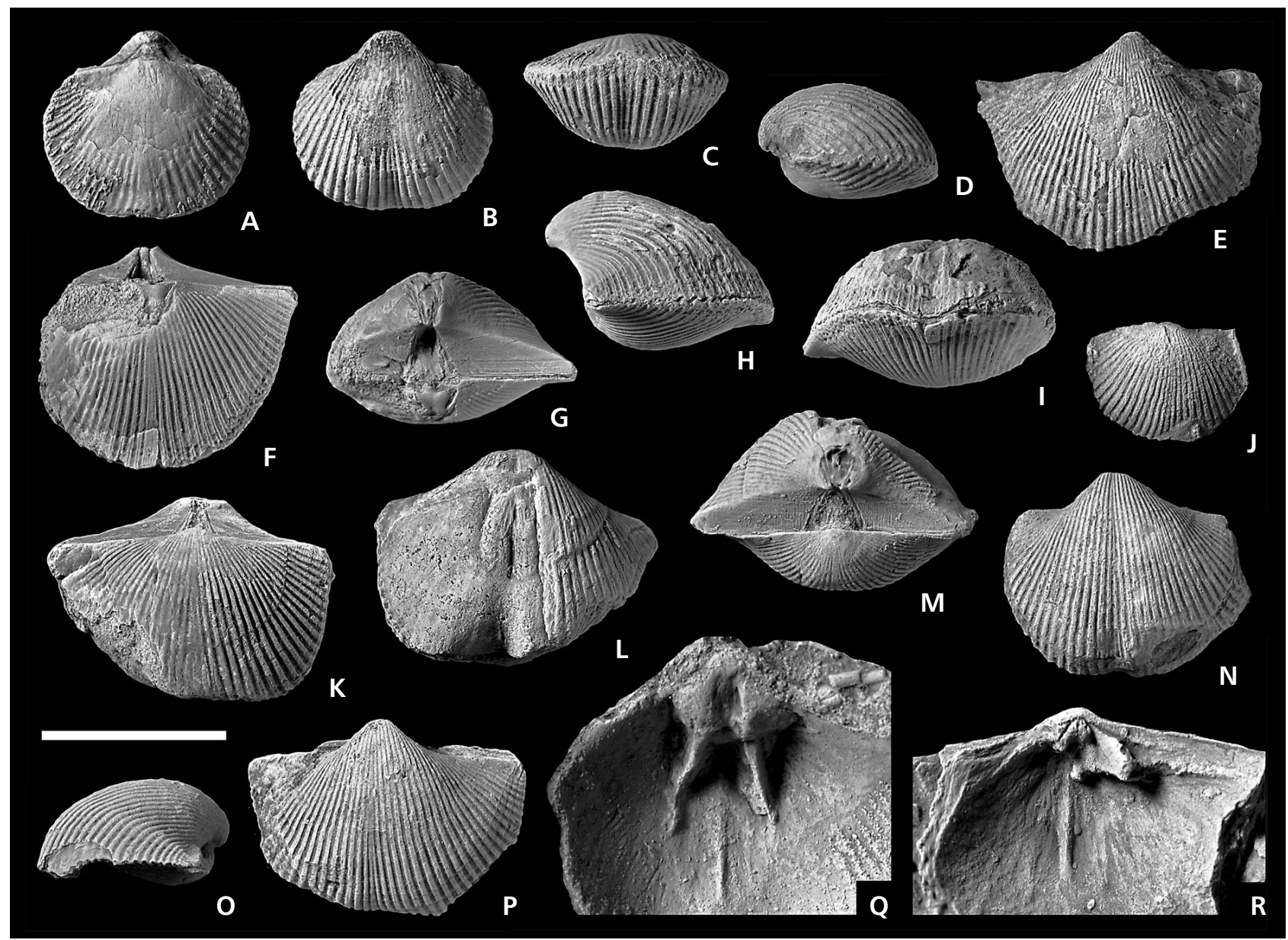

Figure 10. Eodmitria sezgini sp. nov. $\bullet$ A-D - dorsal, ventral, anterior and lateral views, LPB 19319, Tepecik section, level Tr5. $\bullet$ E - ventral valve with poorly expressed sulcus, LPB 19300e, Zincirkıran section. • F-I - dorsal, posterior, lateral and anterior views of the holotype, LPB 19318, Tepecik section, level Tr5. • J - dorsal valve of a juvenile specimen; note the lack of fold and the "chonetid" aspect of the shell, LPB 19303e, Tepecik section, level $\operatorname{Tr} 1$. K-M - dorsal, ventral and posterior views, LPB 19337, Tepecik section, level Tr6. • N - ventral valve with narrow sulcus, LPB 19335 , Tepecik section, level Tr6. O, P - lateral and ventral views of a ventral valve, LPB 19336, Tepecik section, level Tr6. $\bullet$ Q - interior of a ventral valve showing the apical thickening of the shell, the dental plates and a well-marked myophragm, LPB 19300i, Zincirkıran section. $\bullet R-$ interior of a dorsal valve (left part destroyed) showing the elevated cardinal process, the crural plates joining the valve floor and the well expressed myophragm, LPB 19303p, Tepecik section, level Tr1. Scale bar $=1 \mathrm{~cm}$, except for Q, R: scale bar $=0.5 \mathrm{~cm}$.

shell, 4 ventral and 1 dorsal valves), LPB 19301-19303, 19307, 19309, 19310, 19313, 19314, 19318-19321, 19335-19340. Zincirkıran section, CRN1 (13 ventral, 2 dorsal valves and fragments), CRN2 (fragments), LPB $19297,19300$.

Etymology. - After Dr Sezgin Aytuna, Turkish petroleum geologist.

Holotype. - Partially exfoliated shell with conjoined valves, LPB 19318; Tepecik section, level TR 5.

Type locality and age. - Tepecik section, Gümüșali Formation, uppermost Givetian to lower Frasnian.

Diagnosis. - Small Eodmitria with poorly expressed or lacking fold and well delimited shallow sulcus. Strong apical thickening of the shell.

Description. - Shell small (means: $\mathrm{L}=8.4 \mathrm{~mm}, \mathrm{~W}=$ $12.8 \mathrm{~mm}$; Table 3 ), ventribiconvex (mean $\left.\mathrm{H}_{\mathrm{d}} / \mathrm{H}_{\mathrm{v}}=0.5\right)$, entirely costate, with obtuse to rounded cardinal extremities. Width located at or slightly anterior to hinge line (mean $\mathrm{W} / \mathrm{L}=1.5)$. Ventral interarea elevated, apsacline, slightly curved, vertically and horizontally striated. Delthyrium triangular with a relatively narrow base, open and limited by deltidial lamellae. Dorsal interarea poorly expressed with sub-parallel edges.

Sulcus and fold insignificant, costate, very poorly delimited and ill defined with respect to the flanks (mean $\mathrm{W}_{\mathrm{s}} / \mathrm{W}=0.3$ ). The sulcus is somewhat better expressed than fold and appears at some distance from the beak (about 
$1 / 3$ of length) but it remains shallow up to the anterior edge. On the other hand, the fold is invariably lacking in the posterior part of the shell; it may be entirely absent (in this case, the valve mimics a chonetid shell at first glance) or appear in the immediate vicinity of the anterior commissure, although always obscurely. The tongue is virtually lacking, resulting in a feebly uniplicate to rectimarginate anterior commissure.

The shell is entirely costate. The ribs are simple on flanks, with a typically flattened or occasionally (level TR 5) slightly depressed top tending to indicate a tendency to bifurcation particularly near the anterior commissure, although no case of true dichotomy has been observed on the material at hand. On the other hand, some ribs are divided on the fold and in the sulcus. Interspaces between ribs of similar width, with rounded section.

Concentric growth lines are narrow, very closely spaced and feebly marked. Microornament consists of fine radial capillae.

Dental plates are long and thin (?), feebly divergent, located on the edges of the sulcus. Delthyrial plate present. The apical thickening is strong. Elongate, well delimited (including anterior edge) muscle field. Well-expressed median myophragm.

Elevated ctenophoridium consisting of 10 to 12 lamellae. Crural plates well developed, joining the valve floor in their posterior part, although this character may be hidden by the apical thickening of the shell. Sockets straight, deep and very divergent. Strong myophragm extending up to $1 / 3$ of length and tapering abruptly anteriorly.

Discussion. - The poorly expressed sulcus and fold, the flattened ribs lacking divisions on the flanks, the presence of a delthyrial plate and apical thickening of the shell are consistent with an assignment to the genus Eodmitria Brice, 1982. Nevertheless, by contrast with our specimens, in Eodmitria the fold is generally better discernible than the sulcus. Externally, this form is reminiscent of Theodossia Nalivkin, 1925, including the scarcity of branching ribs on the sulcus and fold, but the presence of a delthyrial plate precludes an assignment to the Theodossioidea.

Eodmitria sezgini sp. nov. differs from Eodmitria boloniensis Brice, 1982 (Lower Frasnian of Ferques, France) by its small size, a narrower, badly delimited to lacking sulcus and fold that bear ribs with very few branchings, fewer lateral ribs and a stronger apical thickening of the shell. The cardinal extremities are also more variable in E. sezgini sp. nov. in which mucros may be lacking or poorly expressed. Eodmitria sp. described by Gourvennec (2006) in the eastern Taurids (Kozan area) is larger with wider, relatively better-defined fold and sulcus, has a greater number of ribs and lacks an apical thickening of the shell. Eodmitria oblivialis Sartenaer, 1982 is much larger, almost equibiconvex, with a better-defined fold and sulcus and its lateral ribs may present divisions. Eodmitria? seminoi (Verneuil, 1850) is larger and lacks crural bases. The genus is known in the lower to middle Frasnian of Europe; the presence of Eodmitria sezgini sp. nov. in Turkish Givetian-Frasnian transitional deposits would represent the earliest occurrence of the genus.

Superfamily Ambocoelioidea George, 1931

Family Ambocoeliidae George, 1931

\section{Ambocoeliid ind.}

Figure 7J, K

Material. - Tepecik section, level TR 2 (1 ventral valve), LPB 19308.

Remarks. - Shell very small, entirely smooth. Ventral valve gibbose medially, becoming flattened in the postero-lateral region. Sulcus lacking. Interarea low, apsacline. Beak strong. No foramen observed. Shell surface apparently microspinose with randomly distributed spines.

Interior unknown.

Discussion. - This badly preserved small ventral valve possibly belongs to a spinose genus of the Ambocoeliidae, such as Crurithyris George, 1931, Echinocoelia Cooper \& Williams, 1935 or Crurispina Goldman \& Mitchell, 1990 after its general aspect but the scarcity of the material does not allow drawing further conclusion.

Order Spiriferinida Ivanova, 1972

Superfamily Cyrtinoidea Fredericks, 1911

Family Cyrtinidae Fredericks, 1911

\section{Genus Cyrtina Davidson, 1859}

Type species. - Calceola heteroclita Defrance, 1824.

\section{Cyrtina douvillei Rigaux, 1908}

Figure 7G-I

* 1908 Cyrtina Douvillei; Rigaux, p. 20, pl. 1, fig. 9a-c.

Material. - Tepecik section, level TR 1 (2 ventral valves), LPB 19302, 19303.

Description. - The material only consists of two ventral valves, one of them broken. They are of moderate size $(\mathrm{L} \approx$ $5 \mathrm{~mm}, \mathrm{~W}=10 \mathrm{~mm}, \mathrm{H}=8 \mathrm{~mm}$ for the complete specimen). The shell is punctate, transverse. The interarea is slightly procline to catacline with a small curved beak overhanging 
the interarea. The sulcus is deep, wide (a little less than $1 / 2$ of width), angular, flared, and bounded by costae significantly stronger than lateral ones. The tongue is high, subtriangular to rounded in outline. There are 7 costae on each flank, rounded in section and separated by angular to rounded interspaces. Concentric growth lines narrow, closely spaced, with occasional stronger lamellae indicating growth stasis.

Interior unknown.

Discussion. - The features observed on this specimen are very reminiscent of $C$. douvillei Rigaux, 1908, in particular the strong sulcus bounding costae, the sulcus section and the number of lateral costae. Among closely related species, C. sauvagei Rigaux, 1908 differs in its flattened fold (and rounded to subtrapezoidal outline of the tongue) and its slightly mucronate extremities. In C. inulta Stainbrook, 1945 the sulcus is wider, with a rounded or flattened bottom, and sulcus-bounding costae are not stronger than lateral ones.

C. douvillei is known from the Beaulieu Formation (Northern France, lower Frasnian), the Dinant and Namur basins (Belgium, Frasnian) and the Candas Formation (Spain, Givetian).

\section{Cyrtina sp. cf. C. sauvagei Rigaux, 1908}

Material. - Tepecik section, levels TR 1 (2 fragmentary dorsal valves) and TR 4 (1 fragmentary dorsal valve), LPB 19303, 19313.

Remarks. - This species is represented by three fragmentary dorsal valves with semi-circular outline and angular cardinal extremities. The width is located at the hinge line. The valve is weakly convex, punctate. The fold is narrow, low, not or poorly raised above the flanks, with a flattened top. There are 5 to 8 relatively strong lateral ribs per flank separated by deep, angular, narrow interspaces. The shell surface is microspinose.

The presence of a flattened fold precludes an assignment of this form to C. douvillei Rigaux, 1908 that is characterized by a prominent angular fold. There are some similarities with C. sauvagei Rigaux, 1908 (flattened fold, number of costae), a Givetian-Frasnian species from Northern France and Belgium, but our material is insufficient for a reliable comparison.

C. sauvagei is reported from the Givetian of Northern France (Griset Member of the Blacourt Formation) and the Frasnian of Belgium (Ardenne).

\section{Crinoidea}

Most of the crinoids described herein have been sampled in the Zincirkiran section as isolated ossicles or stem frag- ments. The three identified species are also present in the Tepecik section but are more scarcely distributed in the latter. Articular facets are relatively well preserved but stem fragments are generally weathered, and fine details of the external ornament cannot be identified.

Subclass and order unknown

Group Cyclici Moore \& Jeffords, 1968

Family Fluchticharacidae Moore \& Jeffords, 1968

\section{Genus Laudonomphalus Moore \& Jeffords, 1968}

Type species. - Laudonomphalus regularis Moore \& Jeffords, 1968.

\section{Laudonomphalus sp. ex gr. L. ornatus-regularis} Moore \& Jeffords, 1968 (sensu Le Menn, 1988) Figure 8Q-T

Material. - Tepecik section, TR1 (6 columnals), TR4 (5 columnals), LPB 19303, 19313. Zincirkıran section, CRN1 (4 columnals and 12 stem fragments), CRN2 (29 columnals and 11 stem fragments), LPB 19282-19300.

Description. - Columnals circular in outline. Articular facet concave (medially depressed), entirely covered by crenelae. The latter are numerous, relatively strong, simple or divided distally and more elevated at the periphery of the facet. Lumen small, subpentagonal to rounded, crenulate, bordered by a generally wide perilumen. Latus gently convex, asymmetric, a faint keel occurring at the third of the height of the columnal; although commonly poorly preserved, tubercles have been observed on some specimens (Fig. 8Q).

These elements are compatible with an assignment to the type species of the genus, L. regularis Moore \& Jeffords, 1968, that was described from the Ludlowville Formation, New York, Givetian, and is widely distributed in the Eifelian to Frasnian series of North and South America, Europe (France, Germany) and Russian Federation. The species L. ornatus Moore \& Jeffords, 1968 is very closely related and differs only by the nature of its external ornament (tuberculate $v s$ carinate). As established by Le Menn (in Brice, 1988), the two "species" coexist with intermediate stages of ornament and are probably two morphotypes of the same species.

Family Tantalocrinidae Le Menn, 1985

\section{Genus Tantalocrinus Stukalina, 1975}

Type species. - Tantalocrinus pachydactylus Yeltyscheva \& Stukalina (in Stukalina), 1975. 


\section{Tantalocrinus sp.}

Figure $8 \mathrm{~W}-\mathrm{Y}$

Material. - Tepecik section TR1 (1 columnal), LPB 19301. Zincirkıran section, CRN1 (6 columnals), CRN2 (5 columnals and 1 stem fragment), LPB 19281, LPB 19297, LPB 19300.

Description. - The poorly preserved material prevents a detailed description of these specimens. The columnal is circular. The articular facet is flat, centrally depressed. The lumen is wide and circular. The crenularium is flat, narrow, with numerous crenelae early bifurcating in the vicinity of the lumen. Cirri scars present on one specimen.

The articular facet is similar to that of T. pachydactylus Yeltyscheva \& Stukalina, 1975, type species of the genus that was originally described in the lower part of the Pribalkhash Horizon of Kazakhstan (Lower Devonian). In T. pachydactylus the columnals are externally more convex than in Tantalocrinus sp., with a tuberculate ornament. The genus was recognized in Eifelian to early middle Frasnian of Poland, France and Portugal.

Family Cyclomischidae Moore \& Jeffords, 1968

\section{Genus Paracyclocaudex Le Menn, 1985}

Type species. - Cyclocaudex eodevonicus Le Menn, 1976.

\section{Paracyclocaudex sp.}

Figure 8U, V

Material. - Tepecik section, TR1 (8 columnals), TR4 (8 columnals), LPB 19303, LPB 19313. Zincirkıran section, CRN1 (6 columnals), LPB 19300.

Description. - Columnals circular, thin. Facet flat, bordered by a wide crenularium. Crenelae very fine and numerous, with numerous bifurcations and intercalations occurring at variable distance from the lumen. Lumen of medium size, circular. Paracyclocaudex sp. differs of the type species, P. eodevonicus Le Menn, 1976 (Emsian of the Armorican Massif, France), by its wider crenularium with finer and more numerous crenelae. It differs of $P$. gluziauensis Le Menn, 1985 by its wider lumen and finer crenulae. The genus is reported in Europe in Emsian to Givetian series.

The association of Laudonomphalus sp. ex gr. L. ornatus-regularis and Tantalocrinus sp. is indicative of a late Givetian age (Le Menn, oral comm.).

\section{Conclusions}

These new sections in the Devonian of the Eastern Taurides provide new data on the knowledge of the brachiopod and crinoid faunas in this area of Southern Turkey.

The brachiopod species with the more restricted stratigraphic distribution is $D$. cedulae that is known from the upper Givetian to the lower Frasnian and thus restricts the age of the series to this interval. The other taxa are compatible with such estimation, with variable ranges that overlap or coincide with that of D. cedulae. A noticeable exception is Paillettia that was up to now reported from Early Devonian to Eifelian strata. Among other genera whose coexistence can be problematic here, we should point Holynetes (identified with some reservation) and Eodmitria: the former is considered extinct at the end of the Givetian and the latter normally appears in the lower Frasnian. In the same vein, the presence of Nervostrophia in the upper Givetian and that of Spinulicosta in the lower Frasnian respectively are questionable. The genus Cleiothyridina is rather known from Upper Devonian and Carboniferous strata but earlier occurrences have been recently reported in Upper Givetian in Northern France (Brice et al. 2009). Nevertheless, all these taxa are present in the entire section of Tepecik and therefore, at this stage of our knowledge, it seems reasonable to estimate these levels as representatives of the transition zone from the upper Givetian to the lower Frasnian. This age could probably be refined in the future with further investigations allowing the sampling of better preserved and more numerous specimens that could probably be identified at the specific level. This conclusion is partially confirmed by the crinoid assemblage observed in Darende-Gürün and Van-Zincirkıran areas that indicates a late Givetian age (J. Le Menn, oral comm.), although some elements (remaining here in open nomenclature) would need further investigations.

The presence of two new species Paillettia menae sp. nov. and Eodmitria sezgini sp. nov. that present original, easily identifiable characters is an interesting feature that will allow fine correlations with surrounding areas in future studies. Up to now they are known only in the studied areas (Darende-Gürün and Van-Zincirkıran) and were not reported in the classical sections of the Eastern Taurides (e.g. Feke and Halevikdere) but we suspect that a reexamination of the faunas from the latter sections may reveal their presence here. Although Yalçin \& Yilmaz (2010, fig. 5) place the entire Gümüșali Formation in the Upper Devonian, they admit (p. 241) that older faunas have been recorded in this formation. In particular the conodonts identified by Göncuioğlu et al. (2004) in the lower part of the formation are indicative of a Middle Givetian to Frasnian age. While Sayar et al. (2009) report Frasnian brachiopods from the Gümüșali Formation, they also list some Middle Devonian elements. Thus our results are in accordance with previous works, and it is clear that the lower part of the Gümüșali Formation still belongs to the Upper Givetian or marks a transition from Givetian to Frasnian. 
Despite its insufficient and limited aspect, the faunas described here show some similarities (at least at the generic level) with assemblages described elsewhere in the world, particularly in the North of France (Brice 1988) or Belgium (Mottequin 2008). Apart from its ubiquitous elements, the content of this fossil assemblage as a whole indicates strong affinities with West European faunas, either of Laurussian (e.g. Douvillina cedulae, Cyrtina douvillei) or North Gonwanan domains (e.g. Holynetes or Paillettia, at the generic level). Some elements also indicate affinities with Northern Africa (e.g. Paillettia) or other perigondwanian regions such as Bohemia (Holynetes) or Afghanistan (Aulacella eifliensis). The presence of the latter species also demonstrates that relationships between Turkey and the Russian platform were established during this period while the Rheic Ocean was approaching its closure and was no longer a serious obstacle for trans-oceanic faunal exchanges, a situation favoring a relative homogeneity of the faunas.

The data concerning the crinoids confirm these results. In particular Laudonomphalus ex gr. L. regularis-ornatus is present in North America and Western Europe (Armorican Massif and Northern France), the genus being widely distributed in the world. Tantalocrinus is also widely distributed (Western Europe, Poland, Kazhakstan, etc.), and Paracyclocaudex is present in Western Europe and Moravia.

The abundant remains of bryozoans, solitary corals and the presence of Stromatopora sp. or Cyrtina indicate a peri-reefal environment for these deposits. Most of the shells are broken, indicating a rather rough environment. Some levels consist in thin coquinas beds separated by argillaceous or calcareous interbeds (TR1, TR3), others display a more scattered fauna among fossiliferous surface (TR2).

\section{Acknowledgements}

The authors are grateful to J. Le Menn (Brest University) for the identification of the crinoid columnals. They also wish to thank D. Brice (Lille University, France) and U. Jansen (Senckenberg Museum, Frankfurt, Germany) for their valuable comments that helped to improve the manuscript.

\section{References}

AleKsEeva, R.E. 1960. O novom podrode Atrypa (Desquamatia) subgen. nov. iz sem. Atrypidae Gill (Brakhiopody). Doklady Akademii nauk SSSR 131(2), 421-424.

AtABEy, E. 1993. Stratigraphy of the Gürün autochthon (between Gürün and Sarı), Eastern Taurus-SW Sivas (Turkey). Geological Bulletin of Turkey 36, 99-113.

AtABEy, E. 1996. Facies characteristics and depositional environments of shallow marine carbonates and siliciclastics of Paleozoic Gürün autochthone (Eastern Taurides), SW Sivas, Tur- key. Turkish Association of Petroleum Geologists Bulletin 8, $1-14$.

Aziz, A., Erakman, B., Kurt, G. \& Meșhur, M. 1982. Pınarbașı-Sanz-Gürün ilçeleri arasında kalan alanın jeolojisi raporu. Türkiye Petrolleri Anonim Ortakligi Report 1601, 1-134.

Baykal, F. 1945. Darende ile Kayseri arasındaki Toroslar'in Jeolojik yap1s1. Istanbul University Engineering Faculty's of Earth Sciences Review 10, 2.

Blumenthal, M.M. 1944. The Permocarboniferous of the Taurides between Kayseri Province and Malatya. Bulletin of the Mineral Resource and Exploration Institute 31, 105-118. [in Turkish]

Boucot, A.J., Johnson, J.G. \& Staton, R.D. 1964. On some atrypoid, retzioid, and athyridoid Brachiopoda. Journal of $\mathrm{Pa}$ leontology 38, 805-822.

Brice, D. 1982. Eodmitria, genre nouveau de brachiopode Cyrtospiriferidae du Frasnien inférieur et moyen. Geobios 15(4), 575-581. DOI 10.1016/S0016-6995(82)80073-9

Brice, D. 1988. Brachiopodes du Dévonien de Ferques (Boulonnais - France), 323-395. In BRICE, D. (ed.) Le Dévonien de Ferques. Bas-Boulonnais (N. France). Biostratigraphie du Paléozoïque 7.

Brice, D., Mottequin, B. \& Loones, C. 2009. Découverte de nouveaux brachiopodes dans le Givétien (Dévonien) du Boulonnais (N. France). Annales de la Société géologique du Nord 15, 1-14.

BronN, H. G. 1862. Die Klassen und Ordnungen der Weichthiere (Malacozoa) wissenschaftich dargestellt in Wort und Bild, vol. 3, part 1, Kopflose Weichthiere (Malacazoa Acephala). 518 pp. C.F. Winter'sche Verlagshandlung, Leipzig \& Heidelberg.

BuCKMAN, S.S. 1906. Brachiopod nomenclature: Epithyris, Hypothyris, Cleiothyris Phillips, 1841. Annals and Magazine of Natural History (series 7) 18(107), 321-327.

Bulut, C. 1964. MTA Report. Gürün Bölgesi 1/25.000 ölçekli Elbistan K37-b3,c2,c3 ve K38-a4 paftalarına ait Petrol imkanlar1 Raporu. Maden Tetkik ve Arama Report 4189, $1-202$.

ÇAPKInOĞLU, Ș. \& GediK, I. 2000. Late Devonian Conodont Fauna of the Gümüșali Formation, the Eastern Taurides, Turkey. Turkish Journal of Earth Sciences 9, 69-89.

Carter, J., Johnson, J.G., Gourvennec, R. \& Hou, H.F. 1994. A revised classification of the Spiriferid brachiopods. Annals of the Carnegie Museum 63(4), 327-374.

CASTER, K.E. 1939. A Devonian fauna from Colombia. Bulletins of American Paleontology 24, 1-218.

Chatterton, B.D.E. \& Perry, D.G. 1978. An Early Eifelian invertebrate faunule, Whittacker Anticline, Nortwestern Canada. Journal of Paleontology 52(1), 28-39.

Cooper, G.A. \& WiLliams, J.S. 1935. Tully Formation of New York. Geological Society of America Bulletin 46, 781-868. DOI 10.1130/GSAB-46-781

CoPper, P. 1966. European Mid-Devonian correlations. Nature 209, 982-984. DOI 10.1038/209982a0

Crickmay, C.H. 1950. Some Devonian Spiriferidae from Alberta. Journal of Paleontology 24(2), 219-225.

CRickmay, C.H. 1960. The older Devonian faunas of the Northwest Territories. 20 pp. E. de Mille Books, Calgary.

DAVIDSON, T. 1859 (1858-1863). A monograph of the British fos- 
sil Brachiopoda, Carboniferous, vol. 2, part 5. 280 pp. Palaeontographical Society Monograph, London.

DAvidson, T. 1882. A Monograph of the British fossil Brachiopoda, Devonian and Silurian Supplements, vol. 5, part 1. 134 pp. Palaeontographical Society Monograph, London.

Defrance, J.L.M. [in Blainville, H.M. Ducrotay de 1824 (1825)]. Manuel de malacologie et de conchyliologie. 664 pp. Levrault, Strasbourg.

DemirtașLI, E. 1967. Lithostratigraphic units and petroleum potential of the Pınarbaț-Sarız-Magara region. Maden Tetkik ve Arama Report 4389, 1-112. [in Turkish]

FREDERICKS, G. 1911. Zametka o nekotorykh verkhnepaleozoiskikh okamenelostyakh iz okrectnostei gor. Krasnoufimska. Prilozhenie $k$ protokolam zasiedanii obshchestva estestvoisnytatelei pri Imperatorskom kazanskom universitete 42(269), 1-12.

Fredericks, G. 1919 (1924). Paleontologitcheskie ztoudy. 2: O verkhne kamennougolnykh spiriferidakh Ourala. Izvestyia geologicheskogo komiteta 38(3), 295-324.

García-Alcalde, J. 2005. Upper Emsian Spinelloidea and Cyrtospiriferoidea (Brachiopoda, Spiriferidina) of the Cantabrian Mountains (N Spain). Geobios 38(1), 69-97. DOI 10.1016/j.geobios.2003.06.007

George, T.N. 1931. Ambocoelia Hall and certain similar British Spiriferidae. Geological Society of London, Quarterly Journal 87, 30-61.

GILL, T. 1871. Arrangement of the families of molluscs prepared for the Smithsonian Institution. Smithsonian Miscellaneous Collections 227, 1-49.

Goldman, D. \& Mitchell, C.E. 1990. Morphology, systematics, and evolution of Middle Devonian Ambocoeliidae (Brachiopoda), western New York. Journal of Paleontology 64, 79-99.

GöncÜOĞLU, M.C., GönCüOĞLu, Y., Kozlu, H. \& Kozur, H. 2004. Geological evolution of the Taurides during the Infra-Cambrian to Carboniferous period: A Gondwanan perspective based on new biostratigraphic findings. Geologica Carpathica 55(6), 433-447.

Gosselet, J. 1894. Etude sur les variations du Spirifer Verneuili. Mémoires de la Société Géologique du Nord 4(1), 1-61.

Gourvennec, R. 2006. Upper Devonian brachiopods from Eastern Taurus (Turkey). Geologica Croatica 59(1), 1-17.

GRAY, J.E. 1840. Synopsis of the Contents of the British Museum, $42^{\text {nd }}$ edition. 370 pp. G. Woodfall, London.

HaLl, J. 1843. Survey of the Fourth Geological District. Natural History of New York, Geology 4. 525 pp. Carrol \& Cook, Albany.

Hall, J. 1850. On the Brachiopoda of the Silurian period. Proceedings of the American Association for the Advancement of Science 2, 247-351.

Hall, J. 1857. Descriptions of new species of Paleozoic fossils from the Lower Helderberg, Oriskany Sandstone, Upper Helderberg, Hamilton and Chemung Groups. New York State Cabinet of Natural History, $10^{\text {th }}$ Annual report, part C, Appendix, 41-186.

HaLl, J. 1867. Descriptions and figures of fossil Brachiopoda of the Upper Helderberg, Hamilton, Portage and Chemung Groups. Natural History of New York, Palaeontology 4(1). 428 pp. New York State Geological Survey, Albany.

HAVLíčEK, V. 1956. The brachiopods of the Braník and Hlubo- čepy limestones in the immediate vicinity of Prague. Sborník Ústředního ústavu geologického 22, 535-665.

Havlí̌ex, V. \& Rachebeeuf, P.R. 1979. Chonetacea (Brachiopodes) du Silurien et du Dévonien de Bohême (Tchécoslovaquie). Annales de Paléontologie (Invertébrés) 65(2), 69-138.

Heddebaut, C. 1973. Etudes géologiques dans les Massifs Paléozoïques Basques. 263 pp. Thesis, University of Science and Technology, Lille.

IMBRIE, J. 1959. Brachiopods of the Traverse Group (Devonian) of Michigan. Part 1. Dalmanellacea, Pentameracea, Strophomenacea, Orthotetacea, Chonetacea and Productacea. American Museum of Natural History Bulletin 116(4), 349-409.

Ivanova, E.A. 1972. Osnovnye zakonomernosti evolyutsii spiriferid (Brachiopoda). Paleontologicheskii Zhurnal 1972(3), 28-42.

Johnson, J. G. 1971. Lower Givetian brachiopods from central Nevada. Journal of Paleontology 45(2), 301- 326.

KING, W. 1846. Remarks on certain genera belonging to the class Palliobranchiata. Annals and Magazine of Natural History, London 18, 26-42, 83-94.

KIRANER, F. 1959. Van gölü bölgesinin jeolojik etüdü. Türkiye Jeoloji Kurumu Bülteni 7, 30-57.

KuRtMAn, F. \& AkKuș, F. 1974. Geology and petroleum possibilities of Malatya-Gürün Basin. Türkiye İkinci Petrol Kongresi, Tebliğler, Ankara, 15-24.

Le MAîtRe, D. 1952. La faune du Dévonien Inférieur et moyen de La Saoura et des abords de l'erg El Djemel (Sud-Oranais). Matériaux pour la Carte Géologique de l'Algérie 1, Paléontologie 12, 1-171.

LEBKÜCHNER, R.F. 1976. Beitrag zur Kenntnis des paläozoischen Kerns der Antiklinale von Hazro in Südost-Anatolien. Bulletin of the Mineral Research and Exploration Institute of Turkey $86,1-13$.

Le Menn, J. 1985. Les crinoïdes du Dévonien inférieur et moyen du Massif armoricain. Systématique, paléobiologie, evolution, paléoécologie, biostratigraphie. Mémoires de la Société géologique et minéralogique de Bretagne 30, 1-268.

Le Menn, J. 1988. Echinodermes du Givétien et du Frasnien du Boulonnais (France), 455-477. In BRICE, D. (ed.) Le Dévonien de Ferques. Bas-Boulonnais (N. France). Biostratigraphie du Paléozoïque 7.

Le Menn, J., Plusquellec, Y., Morzadec, P. \& Lardeux, H. 1976. Incursion hercynienne dans les faunes rhénanes du Dévonien inférieur de la Rade de Brest (Massif armoricain). Palaeontographica, Abteilung A 153, 1-61.

MA, X. \& DAY, J. 2003. Revision of selected North American and Eurasian Late Devonian (Frasnian) species of Cyrtospirifer and Regelia (Brachiopoda). Journal of Paleontology 77(2), 267-292.

DOI 10.1666/0022-3360(2003)077<0267:ROSNAA >2.0.CO;2

MENKE, C.T. 1828. Synopsis methodica molluscorum generum omnium et specierum earum quae in Museo Menkeano adservantur. 91 pp. G. Uslar, Pyrmonti.

Moore, R.C. \& JeFFords, R.M. 1968. Classification and nomenclature of fossil Crinoids based on dissociated parts of columns. University of Kansas Paleontological Contributions, Echinodermata 9, 1-86.

MotTequin, B. 2008. Late middle Frasnian to early Famennian (Late Devonian) strophomenid, orthotetid, and athyridid 
brachiopods from Southern Belgium. Journal of Paleontology 82(6), 1052-1073. DOI 10.1666/07-086.1

Murchison, R.I. 1840. Description de quelques-unes des coquilles fossiles les plus abondantes dans les couches dévoniennes du Bas-Boulonnais. Bulletin de la Société géologique de France 11, 250-257.

Muir-Wood, H.M. 1955. A history of the classification of the Phylum Brachiopoda. British Museum (Natural History) London, 1-124.

Muir-Wood, H.M. 1962. On the morphology and classification of the brachiopod suborder Chonetoidea. British Museum (Natural History), Monograph, 1-132.

NALCIOĞLu, E.G. 2004. The Frasnian brachiopod fauna from Late Devonian Gümüșali formation in Saimbeyli region (Adana-Eastern Taurus). Bulletin of the Mineral Resource and Exploration Institute 129, 57-68.

Nalivkin, D.V. 1925. Gruppa Spirifer Anossofi Vern. i devon evropeiskoi chasti SSSR. Zapiski Rossiiskogo mineralogicheskogo obshchestva 54(2), 267-358.

NALIVKIN, D.V. 1937. Brakhiopody verkhnego i srednego devona i nizhnego karbona severo-vostochnogo Kazakhstana. Tsentral'nyi nauchno-issledovatel'skii geologo-razvedochnyi institut (TSNIGRI), Trudy 99, 1-200.

NaZiK, A., Yalçin, N.M., Wilde, V., Wehrmann, A., Yilmaz, I., Schindler, E., Kozlu, H. \& BozdoĞAn, N. 2012. Paleoecology and paleogeography of ostracods from the Devonian of Halevikdere (Eastern Taurides, Turkey), 35-36. In Yalçin, N.M., ÇORbacioĞLu, H., Aksu, Ö. \& BozdoĞan, N. (eds) Paleozoic of Northern Gondwana and its Petroleum Potential, a field workshop, 9-14 September. Turkish Association of Petroleum Geologists, Special Publication 6.

NoRTH, F.J. 1920. On Syringothyris Winchell and certain Carboniferous Brachiopoda referred to Spiriferina d'Orbigny. Geological Society of London, Quarterly Journal 76(2), 162-227.

OenLERT, D.P. 1887. Appendice: Brachiopodes; notions sur l'anatomie et la physiologie des brachiopodes, 1189-1334. In FISCHER, H. (ed.) Manuel de Conchyliologie et de Paléontologie conchyliologique ou histoire naturelle des Mollusques vivants et fossiles 11.

OenLert, D.P. 1888. Description de quelques espèces dévoniennes du département de la Mayenne. Bulletin de la Société d'études scientifiques d'Angers 17(1887), 65-120.

ÖрIK, A.A. 1934. Über die Klitamboniten. Tartu Ulikooli Geoloogia-Instituudi Toimestuesed Acta et Commentationes Universitatis Tartuensis 39, 1-239.

ORTYNiski, I. 1944. Geological report on a trip to Van arca. Maden Tetkik ve Arama Report 1519, 1-97.

ÖzGÜL, N. 1976. Torosların bazı temel jeolojik özellikleri. Türkiye Jeoloji Kurumu Bülteni 19, 65-78.

ÖzGüL, N., Metin, S. \& Dean, W.T. 1972. Stratigraphy and faunas of the Eastern Taurus Mountains in the Tufanbeyli region, Southern Turkey. Bulletin of the Mineral Resource and Exploration Institute 79, 9-16.

Özgül, N., Metin, S., ERdoĞan, B., GoĞER, E., Bingöl, I. \& BAYDAR, O. 1973. Tufanbeyli dolayının Kambryien ve Tersiyer kalayar1. Bulletin of the Geological Society of Turkey $1,82-100$.

Patrut, I. 1968a. Doğu Türkiye'deki Hidrokarbon Aramaları Hakkında Not. Maden Tetkik ve Arama Report 20158, 74.
Patrut, I. 1968b. Doğu Türkiye'deki Hidrokarbon Aramaları Hakkında Not (Darende-Gürün alanı). Maden Tetkik ve Arama Report 20161, 42.

Rachebeuf, P.R. 1981. Chonetacés (Brachiopodes) siluriens et dévoniens du Sud-Ouest de l'Europe. Mémoire de la Société géologique et minéralogique de Bretagne 27, 1-294.

Rachebceuf, P.R., Gourvennec, R., Deynoux, M. \& Brice, D. 2004. The Devonian of the Hodh area (Islamic Republic of Mauritania): Paleontology, stratigraphy and paleobiogeographic implications. Journal of Paleontology 78(1), 98-110. DOI 10.1666/0022-3360(2004)078<0098:TDOTHA >2.0.CO;2

RAYMond, P.E. 1911. The Brachiopoda and Ostracoda of the Chazyan. Annals of the Carnegie Museum 7(2), 215-259.

RigauX, E. 1872. Notes pour servir à la géologie du Boulonnais. 1. Description de quelques brachiopodes du terrain Dévonien de Ferques. Mémoires de la Société académique de l'arrondissement de Boulogne sur Mer 5, 1-16.

Rigaux, E. 1908. Le Dévonien de Ferques et ses Brachiopodes. 33 pp. Deligny, Boulogne sur Mer.

Rzhonsnitskaya, M.A. 1960. Order Atrypida, 257-264. In Orlov, Y.A. (ed.) Osnovy paleontologii, Vol. 7. Akademia nauk SSSR, Moscow.

SARTENAER, P. 1966. Commentaires sur le genre nominal Adolfia Gürich, G., 1909 et sur le nom générique Guerichella (Brachiopoda, Spiriferacea). Bulletin de la Société belge de géologie, paléontologie et hydrologie 75(3), 380-389.

SARTENAER, P. 1982. The presence and significance of Spirifer bisinus, S. malaisi, S. supradisjunctus, and S. seminoi in early Frasnian beds of Western Europe, 122-196. In SARTEnAER, P. (ed.) Papers on the Frasnian-Givetian Boundary. Ministry of Economic Affairs, Administration of Mines and Geological Survey of Belgium, Brussels.

SARYTChEVA, T.G. \& SoKolskaya, A.N. 1959. O klassifikatsin lozhnoporistykh brakhiopod. Akademiia nauk SSSR, Doklady 125(1), 181-184.

SAYAR, C., Yilmaz, I. \& Bargu, S. 2009. Stratigraphy and fossils of Middle, Upper Devonian and Carboniferous from Saimbeyli, Eastern Taurides, Turkey. Türkiye Jeoloji Kurultay 62, 664-665.

SchnuR, J. 1853 (1854). Zusammenstellung und Beschreibung sämmtlicher in Uebergangsgebirge der Eifel vorkommenden Brachiopoden nebst Abbildungen derselben. Palaeontographica 3, 169-247.

SCHUCHeRT, C. 1913. The Lower Devonian deposits of Maryland. Class Brachiopoda, 290-449. Maryland Geological Survey, Baltimore.

SChUCheRT, C. 1929. Classification of brachiopod genera, Fossil and Recent, 10-25. In PoMPECKJ, J.F. (ed.) Fossilium Catalogus 1: Animalia, pars 42: Brachiopoda. W. Junk, Berlin.

Schuchert, C. \& Cooper, G. A. 1931. Synopsis of the brachiopod genera of the suborders Orthoidea and Pentameroidea, with notes on the Telotremata. American Journal of Science (series 5) $22,241-255$.

Schuchert, C. \& Cooper, G.A. 1932. Brachiopod genera of the suborders Orthoidea and Pentameroidea. Memoirs of the Peabody Museum of Natural History 4(1), 1-270.

ȘENEL, M. 1987. 1/100 000 ölçekli açınsama nitelikli Türkiye Jeoloji Haritaları Serisi. Bașkale-H38 Paftası. 12 pp. Maden Tetkik ve Arama Genel Müdürlüğü, Ankara. 
Șenel, M., Acarlar, M., Çakmakoğlu, A., Dağer, Z., Erkanol, D., Örçen, S., Tașkiran, M.A., Ulu, U., Ünal, M.F. \& YILDIRIM, H. 1984. Özalp (Van)-İran sınırı arasındaki alanın jeolojisi (Bașkale-K52). Maden Tetkik ve Arama Report 7623, $1-167$.

Sowerby, J. DE C. 1840-1846. The Mineral Conchology of Great Britain 7. 80 pp. London.

StainBrooK, M.A. 1945. Brachiopoda of the Independence Shale of Iowa. Geological Society of America Memoir 14, 1-74. DOI 10.1130/mem14-p1

Struve, W. 1966. Einige Atrypinae aus dem Silurium und Devon. Senckenbergiana lethaea 47(2), 123-163.

Stukalina, G.A. 1975. Morskie lilii, 133-150. In Menner, V.V. (ed.) Karakteristika fauni progranitsnikh sloev silura i devona tsentralnogo Kazakhstana. Materialy po geologii tsentralnogo Kazakhstana 12.

Termier, H. \& Termier, G. 1949. Essai sur l'évolution des spiriféridés. Division des Mines et de la Géologie, Service Géologique, Notes et Mémoires, Notes du Service Géologique (Tome 2) 74B, 85-112.

TutKun, S.Z. 1984. Stratigraphy of Saimbeyli (Adana) area. Cumhuriyet Universitesi, Bulletin of the Faculty of Engineering, Earth Sciences 1(1), 31-40.

ÜNSAlaner, C. 1951. Some Upper Devonian corals and stromatoporoids from South Anatolia. Bulletin of the Geological Society of Turkey 3, 131-146.

Verneuil, E. DE 1850. Note sur les fossiles dévoniens du district de Sabero (León). Bulletin de la Société géologique de France ( $2^{\text {nd }}$ series) $7,155-186$
WaAgen, W.H. 1883. Salt Range Fossils. I. Productus Limestone Fossils. Memoirs of the Geological Survey of India, Palaeontologia Indica (series 13) 4(2), 391-546.

WaAgen, W.H. 1885. Salt Range Fossils. I. Productus Limestone Fossils, Brachiopoda. Memoirs of the Geological Survey of India, Palaeontologia Indica (series 13) 5, 729-770.

Wehrmann, A., Yilmaz, I., Yalçin, M.N., Wilde, V., Schindler, E., Weddige, K., Saydam Demirtas, G., ÖZkan, R., NaziK, A., NalcioĞlu, G., Kozlu, H., KarslioĞlu, Ö., Jansen, U., Ertug, K., Brocke, R. \& BozdoĞan, N. 2010. Devonian shallow-water sequences from the North-Gondwana coastal margin (Central and Eastern Taurides, Turkey): Sedimentology, facies and global events. Gondwana Research 17(2-4), 546-560. DOI 10.1016/j.gr.2009.09.011

Webster, G.D., Yilmaz, I. \& Kozlu, H. 2008. A new Middle Devonian gasterocomid crinoid from Central Turkey and revision of the Gastrecomidae. Palaeoworld 17, 12-20. DOI 10.1016/j.palwor.2007.12.001

Williams, A. 1965. Suborder Strophomenidina, 362-412. In Moore, R.C. (ed.) Treatise on invertebrate paleontology. Part $H$, Brachiopoda. Geological Society of America \& University of Kansas Press, New York \& Lawrence.

Yalçin, N. \& Yilmaz, I. 2010. Devonian in Turkey, a review. Geologica carpathica 61(3), 235-253.

Zahn, G.W. von 1906. Die Stellung Armeniens im Gebirgsbau von Vorderasien unter besonderer Berücksichtigung der türkischen Teile. Veröffentlichungen des Instituts für Meereskunde und des Geographischen Instituts an der Universität Berlin 10, 1-89. 